\title{
2.7 \\ ESTETISK VARIATION \\ I VÄVNING OCH BRODERI
}

\author{
Anneli Palmsköld
}

I detta kapitel kommer de olika former av dekorerade och mönstrade textilier som förekom i den hälsingska inredningskulturen att presenteras och analyseras. Syftet är att undersöka hur hantverkarna har skapat estetisk variation genom användning av kulörer och mönster. De textilier som har undersökts ingår i samlingarna på Hälsinglands museum i Hudiksvall, Ljusdalsbygdens museum i Ljusdal, Delsbo hembygdsoch fornminnesförening i Delsbo, Järvsö hembygdsförening och Brita Åsbrinks samling ${ }^{88}$ i Järvsö, Gården Bortom Åa i Fågelsjö och i privata samlingar. ${ }^{89}$ Dessa samlingar domineras av broderade inredningstextilier, men även spetsar och vävnader förekommer. Vidare har Hedvig Ulfsparres bibliotek och samling, liksom utställningen Smaken och kapitalet på Länsmuseet Gävleborg i Gävle studerats. På Nordiska museet ${ }^{9 \circ}$ i Stockholm har inredningstextilier med proveniens Hälsingland studerats. Lilli Zickermans manuskript till det planerade samlingsverket Sveriges folkliga textilkonst innehåller inventerat material från Hälsingland. Manuskripten och det rikliga bildmaterialet som finns i Nordiska museets arkiv har analyserats och undersökts. Sammanfattningsvis har såväl textilier som de analyser som gjordes av dem när de kom att ingå i samlingar och inventeringar använts som empiriska källor i kapitlet.

88. Tack till Elisabeth Fransson för intressanta diskussioner och för delande av kunskaper om Brita Åsbrinks omfattande textila verksamhet.

89. Tack till Susanne Klingefors, Hälsinglands museum i Hudiksvall för generös hjälp med att identifiera intressanta samlingar och för insiktsfulla diskussioner. Tack också Brita Björs samt f.d. länsantikvarie Erik Nordin och Elina Antell.

90. Tack till intendent Ulla-Karin Warberg, Nordiska museet, för generös hjälp med uppgifter och tillgång till källmaterial. 


\section{Metoder, källor och källkritik}

Flera samverkande metoder har använts i denna undersökning av estetisk variation i textilier genom kulörer och mönster. Inredningstextilier i privata och offentliga samlingar har undersökts visuellt och taktilt. Anteckningar har förts och fotografier har tagits på såväl hela textilier som på detaljer. Samtidigt har dokumentation av proveniens och andra historiska uppgifter av värde antecknats. I vissa fall har prover tagits på trådar för att undersöka vilka färgämnen som har använts. Uppgifter på katalogkort och i bilagor till dessa har noterats. Ur källkritisk synpunkt är det viktigt att vara medveten om att de samlingar av föremål som har bevarats är resultatet av en blandning av slump och urval (se Palmsköld 2007, 2018). Det är också viktigt att vara medveten om de olika tidslager, brukspraktiker och transformationer som föremål kan bära vittnesbörd om. Vidare kan materialen ha förändrats genom slitage och nedbrytning. Det är vanligt att färgnyanser har förändrats eller bleknat. Ofta kan dock originalnyanser finnas kvar i invikta fållar eller på avigsidor som inte har utsatts för solljus.

Lilli Zickermans handskrivna manuskript till Sveriges folkliga textilkonst samt de fotografier hon kontinuerligt hänvisar till har analyserats och tolkats. Handskriften har varit möjlig att läsa och tyda, med undantag för enstaka ord. De svartvita fotografierna är av varierande kvalitet och i huvudsak tagna för att visa textilier i sin helhet och är därför av karaktären översiktsbilder. Manuskripten kräver uppmärksam läsning tillika förkunskaper i textila material, tekniker och hantverk. Sättet att strukturera och dela in textilierna följer en viss logik, som inte diskuteras eller artikuleras tydligt.

Det är dock viktigt att komma ihåg den bakomliggande idén med inventeringen: Zickerman ville lyfta fram kvinnornas bidrag till konsten samt uppmärksamma de folkliga textilierna och de varierande ortskaraktäristiska uttrycken som en motsats till de industritillverkade produkterna. Hon såg både estetiska, materiella och hantverksskickliga kvaliteter i materialet. I arbetet valde hon ut det som skulle ingå i inventeringen, men hon valde också bort det som inte passade in i den geografiska kartan över det hon betraktade som ortskaraktäristiska textila tekniker. Ett exempel på detta är tekniken virkning, som trots att den förekom i Hälsingland inte inventerades (se även Palmsköld 2017). Det kan vara ett skäl till skillnader mellan vad Zickerman såg, dokumenterade och beskrev och vad som framkommit i undersökningen i 
forskningsprojektet. Andra exempel än virkning, är tekniker som näversöm och flätningar. Dessa förekommer inte i någon större omfattning $\mathrm{i}$ de samlingar som har undersökts.

Inredningstextilier i samlingar har varierande uppgifter om proveniens och tillverkning. De som ingår i privata samlingar knutna till familjer och släkter, kan i vissa fall attribueras genom traderade kunskaper eller genom broderade monogram och årtal som kan härledas till släktingar. I de fall ägarmärkning saknas, är mer precisa dateringar svåra att göra även om materialval, tekniker, färger och estetiska uttryck kan ge ledtrådar. Textilierna har oftast behandlats och betraktats som enskilda objekt, vilket gör det svårt att hitta säkra belägg för hur de har använts tillsammans och kombinerats med varandra och med andra inventarier i en inredning. Det är också svårt att veta deras exakta placering. Den historieskrivning som behandlar textilierna har formats av kulturarvsaktörer verksamma på museer, hembygdsföreningar och inom hemslöjdsrörelsen. Dessa har inventerat, dokumenterat, samlat in, beskrivit och analyserat textilier och inom ramen för hemslöjdsrörelsen har kunskaperna om själva görandet utvecklats, förvaltats och lärts ut (jfr Palmsköld 2017). Detta har skett genom kursverksamhet, publicering av böcker med mönster samt försäljning av material och beskrivningar i de hemslöjdsbutiker som rörelsen drev i varje län under större delen av 1900-talet (ibid.). De som en gång tillverkade och använde textilierna i inredningarna, är ofta frånvarande, även om resultaten av deras hantverkande finns kvar. ${ }^{91}$

\section{Inventering och samlingar}

Lilli Zickerman (1858-1949) räknas som den svenska hemslöjdsrörelsens grundare genom bildandet av Föreningen för Svensk Hemslöjd 1899. ${ }^{92}$ Efter att ha varit verksam som föreståndare för föreningens butik i Stockholm, inledde hon arbetet med inventeringen Sveriges folkliga textilkonst som räknas som en av de mest omfattande kulturhistoriska inventeringarna som har genomförts i Sverige och som pågick under åren 1914-1931. Inventeringen består av cirka 24000 svartvita foto-

91. För en kritisk diskussion om hur insamling och dokumentation gick till under slutet av 1800-talet samt om varför röster från textilhantverkare saknas, se Palmsköld 2007.

92. Detta avsnitt bygger på Zickerman 1999 och Palmsköld 2018. 
grafier, flera delvis kolorerade, dokumentärfilmer om svensk hemslöjd som visar olika typer av tekniker samt 27 handskrivna manuskript som utgör en analys av det samlade materialet. Tanken var att ge ut dessa i ett omfattande bokverk, men endast den första delen gavs ut (Zickerman 1937). Det samlade materialet ingår idag i Nordiska museets arkiv, delar av inventeringen finns i form av dubbletter av fotografier i en studiesamling på Konstfack i Stockholm. ${ }^{93}$

Inventeringen är sorterad efter teknik och landskap, vilket gör den lämplig att studera för att få fördjupad kunskap om de inredningstextilier som förekom i Hälsingland kopplade till fenomenet hälsingegårdar. Hela arbetet bygger på Zickermans idé om den ortskaraktäristiska slöjden, med mönster och tekniker som särskiljer sig och som har en lång historia på en ort (Zickerman 1999; Palmsköld 2012ab). Redan i titeln på inventeringen anges vad det handlar om: nationen som rum där landskap och orter står i fokus; erkännande av folkets och särskilt kvinnornas skicklighet i slöjd och hantverk samt den estetiska inriktning som arbetet hade. De folkliga textilierna betraktades som uttryck för textilkonst och det framgår att Zickerman ansåg att detta var kvinnornas bidrag till konsten när hon inledningsvis skriver att: "Det är den svenska kvinnans kulturella och konstnärliga insats under århundraden som här framträder inför våra ögon" (Zickerman, del I, Sveriges folkliga textilkonst). Inventeringen, menar hon, kommer att finnas kvar även när textilierna i sig inte längre finns - den "visa nu kommande generationer hur befolkningens inneboende skönhetskraf tillfredsställdes genom husmödrarnas kunnighet, flit och omtanke" (ibid.). Det är värt att notera att begreppet "folkkonst" inte förekommer i inventeringen, däremot ordet "folkslöjd" behandlar flossa, skriver hon att inventeringen "står utanför den rent historiska och vetenskapliga forskningen" och istället är avsikten "att i bilder, med därtill hörande vägledande text, framlägga en lätt överskådlig öfversigt af mönstertypernas fördelning inom Sveriges skiljda landskap" (Zickerman, del XI, Flossa). Denna översikt skulle bidra till kunskaper om skilda estetiska uttryck och lösningar som förekommer och kan studeras i de folkliga textilierna. Men även om Zickerman betonar inven-

93. Studiesamlingen på Konstfack håller för närvarande på att digitaliseras för att ingå i Digitalt museum, se https://hemslojden.org/fa-kunskap/ hemslojdenssamlingar/.

94. Hon använder även begreppet "bygdebetonad folkslöjd" (ibid.). 
teringens visuella inriktning och verkets översiktliga karaktär, framgår det av manuskripten att hon väl kände till tidens ledande forskare inom textilämnet då hon ibland hänvisar till dessas arbeten.

Vad är det då som Zickerman särskilt lyfter fram? En av de viktigaste frågorna som hon återkommer till i manuskripten, är hur tekniker kan karaktäriseras i olika typer och beroende på var de har utövats (ortskaraktäristiken). Vidare diskuteras eventuella risker för sammanblandningar och hur dessa kan undvikas. Arbetet ska hjälpa läsaren att identifiera, känna igen och benämna olika uttryck av den svenska folkliga textilkonsten. Ett sätt att översiktligt undersöka hur textilier från Hälsingland presenteras i Sveriges folkliga textilkonst är att beskriva under vilka tekniskt orienterade rubriker textilier från landskapet nämns, det är: krabbasnår, rosengång, dubbelvävnad, flossa, linnebottenstäcken, broderi på linne, knyppling och knytning. Mest frekvent diskuteras och presenteras textilier från Hälsingland i texter om broderi på linne, flossa, linnebottenstäcken samt knyppling. Ett annat sätt att utifrån Zickermans inventering göra sig en bild av Hälsinglands textilkonst är att systematiskt gå igenom materialet och beskriva vilka enskilda textilier och textila tekniker som ingår i inventeringen. Detta görs i korthet i det följande.

\section{Krabbasnår}

De textilier som är avfotograferade för att illustrera hur vävtekniken krabbasnår användes, är täcken vävda i två längder och hopsydda på mitten. I flera fall rör det sig om fragment av gamla vävnader i krabbasnår. Fotografierna visar hur mönsterbilderna skiljer sig mellan socknar som Bjuråker, Delsbo och Ljusdal. Zickerman drar slutsatsen "att typen varit allmänt utbredd öfver landskapet" (Zickerman, del II, Krabbasnår). Enligt inventeringen finns flest täcken i Delsbo och dessa är mer mönstrade, med klara och lysande färger mot en svart botten.

\section{Rosengaing}

I volymen om rosengång beskriver Zickerman hur benämningen först användes av Jacob Kulle i Georg Karlins Skånsk textil konstslöjd som gavs ut $1886^{95}$ och som leder till distinktionen mellan modern lös (liksidig) och äldre bunden (oliksidig) rosengång (Zickerman, del VI, Rosengång). Zickerman menar att mönstren som möjliggörs genom teknik

95. I S AOB anges att ordet först används år 1880 (rosengång, www.saob.se). 
och färgväxlingar, gör att väverskan kan sätta sin personliga prägel på vävnaden. Hon delar upp rosengångsvävnader i tre grupper baserade på hur de mönstras: a) hel mönstring, b) mönstrade partier åtskilda av mörka partier som är lika stora samt c) "en taggformig, mångfärgad formbildning" som kan struktureras över ytan enligt a eller b. I Hälsingland förekommer den bundna rosengången (vävd på fyra skaft till skillnad från i södra Sverige där den vävdes på tre skaft) och tre typer identifieras: a) breda mönstrade partier med smala mörka ränder, b) breda mörka ränder med lika breda mönstrade fält i klara och lysande färger samt c) "färgrika band mer eller mindre breda, och på större eller mindre afstånd från hvarandra, sträckta öfver en mörk yta" (ibid.). Den sistnämnda typen dateras till 1800-talet. Rosengång användes, i likhet med krabbasnår, för att väva täcken som var hopsydda på mitten.

I den undersökning som har genomförts i forskningsprojektet förekommer rosengång även på kuddvar/örngottshuvuden och på handkläden. Här har vävda stycken sytts fast som dekoration, materialet som har använts är bomull i rött och vitt och rosengång förekommer i mönstrade ränder som åtskiljs av vita partier (se t.ex. XJG T 1490 och XJG 98). Tekniken har också använts på slarvtäcken där de förekommer som dekorativa, smala ränder i starka färger som kontrasterar mot den ljusa bottenväven (se t.ex. XJG 666).

\section{Halvflossa}

Täcken i halvflossa (en form av rya), så kallad slarvtjäll, beskrivs i Zickermans inventering. De vävdes i varp av grovt lingarn och med inslag av trasor och garn (Zickerman, del XI, Flossa, bd I). På en generell nivå delar Zickerman in ryorna i tre kategorier: slitryan som används till vardags, den folkligt betonade prydnadsryan med rikliga mönster samt högreståndsryan där "mönsterbildningen står på en nivå som ställer den utanför folkets oskolade förmåga" (ibid.). I det andra bandet om Flossa anges att ryor förekommer ofta och att i vissa socknar finns ett stort bestånd som i Järvsö och Ljusdal, men i andra inget alls (Zickerman, del XI, Flossa, bd II). Så här beskrivs ryornas estetiska och formmässiga karaktär:

Bottenväfnaden är $i$ regel svart och mönstergarnets färger äro: rödt, blått, grönt och hvitt. Där gult någon gång förekommer är det så ljust att det användes istället för hvitt.

Formmotivet är den spetsställda rutan, sällan synes den hori- 


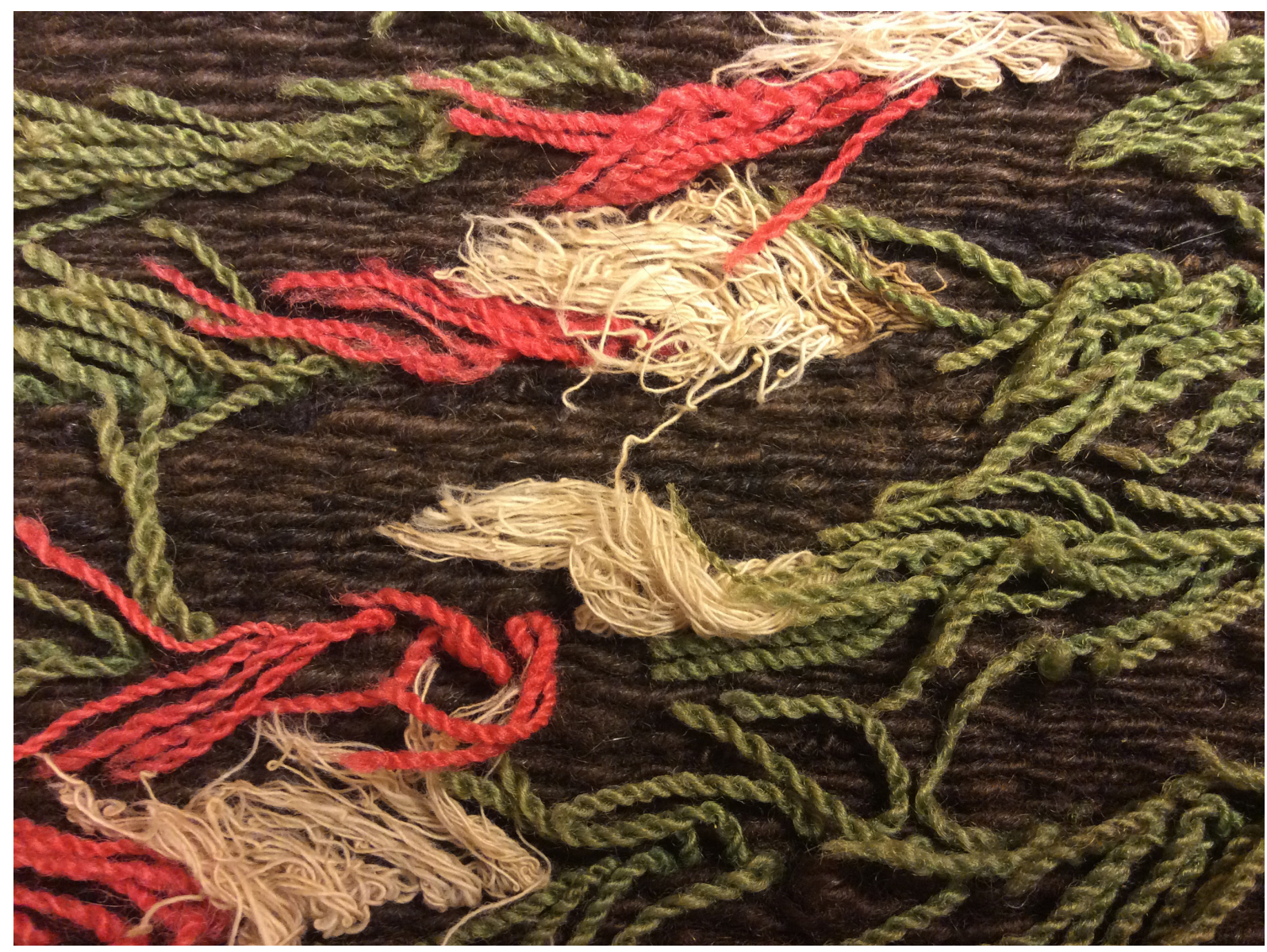

Figur 1 (2.7.1):

Detaljbild av en rya med en mörk botten och inslag av tvåtrådiga gröna och röda garner samt entrådigt ljust gult garn. Ägs av Ljusdalsbygdens museum (LjM 6123). Foto: Anneli Palmsköld sontalt ställda. I några af socknarne är färgerna inplockade fläckvis, tillsynes utan all beräkning (ibid.).

Zickerman ger bildexempel på alla tre former av ryor och anger att slitryan främst förekommer i Järvsö medan många prydnadsryor förekommer i Ljusdal. Bland slitryorna förekommer inte bara "den spetsställda rutan", utan även andra rombformer samt sicksack-formade mönster. I prydnadsryorna ökar komplexiteten i mönstren och i exemplen förekommer mänskliga skepnader, djur-, träd- och växtformer. Bildmaterialet avslutas med fyra "högreståndsryor", som illustrerar Zickermans uppfattning om ett mer professionellt förhållningssätt i mönstringen. I de flesta fall är täckena komponerade med kantbårder och en yta för mönster i mitten.

I de offentliga och privata samlingar som undersökts i forskningsprojektet förekommer liknande ryor som beskrivs ovan, med en tonvikt på prydnadsryor. Det finns också exempel på ryor där extra arbete har lagts ned på kompositionen och där monogram och årtal har vävts in. I 


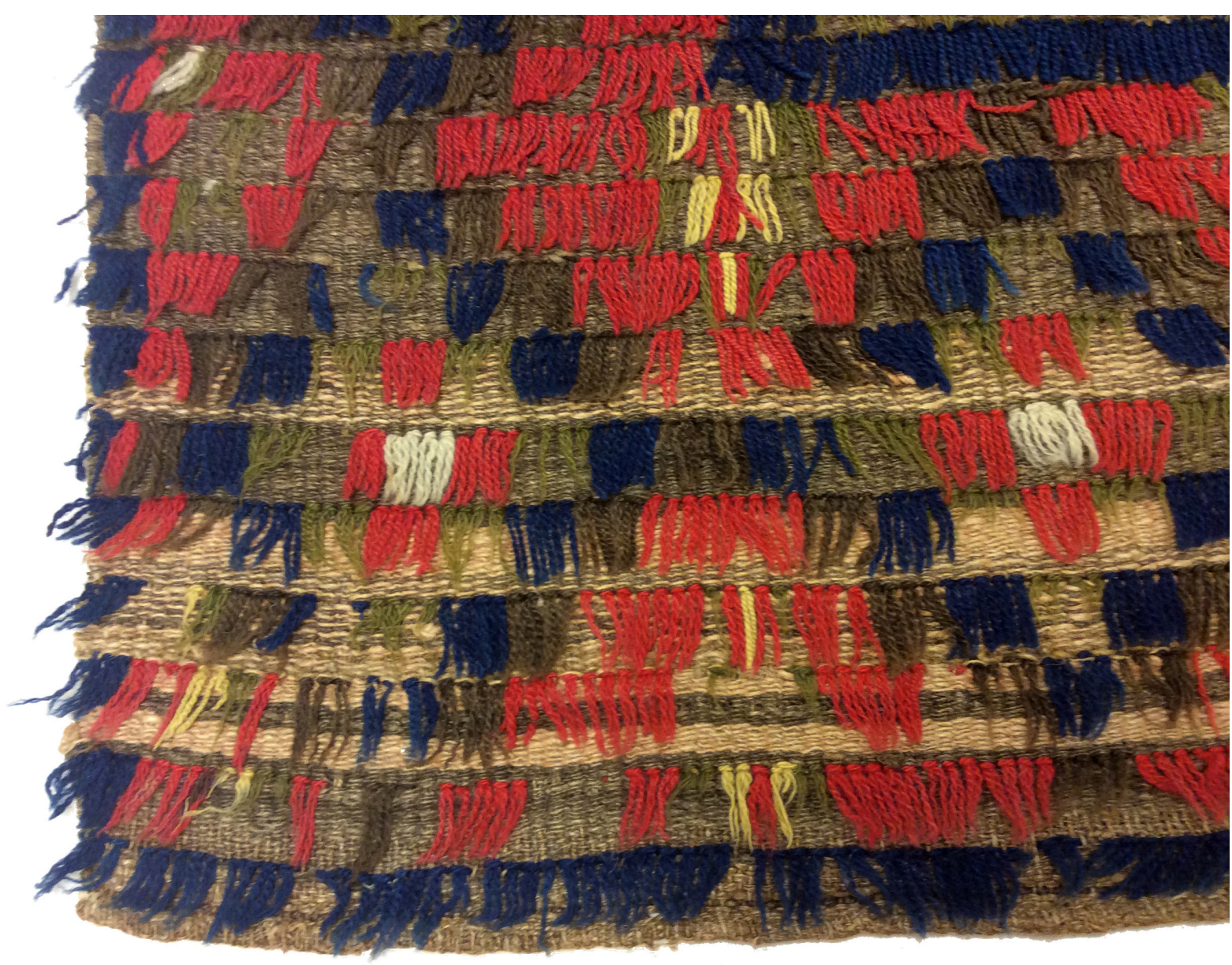

ett fall är ryan i privat ägo och det är känt att den vävdes inför vigseln av ett par som båda var födda 1784 (samtal med Anders Assis 2015-02-17).

\section{"Linnebottenstäcken"}

I två band redovisar Zickerman det som hon kallar "linnebottenstäcken", där både varp och inslag är av linne. Här fortsätter analysen av täckena i slarvtjäll och fler lokala benämningar tas upp som trasrya och sluns (Zickerman, del XII, Linnebottenstäcken, bd I). Dessa täcken skiljer sig i uttryck jämfört med ryorna ovan. Eftersom inventeringen endast innehåller översiktsbilder över textilierna i sin helhet, innebär det att de trasor och garn som användes som inslag inte får någon vidare uppmärksamhet.

Bland textilierna som har analyserats i forskningsprojektet förekommer garnknippen i olika färger och kvaliteter; små klippta bitar av vävda linnetyger samt röda, gröna, svarta och mörkt blå ylletyger; stickade bitar i rött ullgarn med avigsidan utåt (troligen för att skapa en

Figur 2 (2.7.2): Detalj av rya, linnevarp med inslag av ullgarn och lugg i rött, blått, grönt, gult och brunt ullgarn som bildar mönster. Ägs av Ljusdalsbygdens museum (LjM 7714). Foto: Anneli Palmsköld 
mönster vandrar och sprids. Även om beskrivningen av hur knallarna verkade för att utveckla sina sortiment kan stämma, saknas skriftliga empiriska belägg.

Täckena är helmönstrade, där mönstren struktureras som tvärgående eller längsgående ränder eller som rutor. Bottenväven är vävd i lingarn, mönsterinslagen går i bruna, gula och gröna nyanser av ullgarn och bildar en kontrast mot det ljusa som gör att mönstren framträder. Vissa täcken har ett mönsterparti i mitten, så kallade prästrutor. Zickerman menar dock att de är så ovanligt förekommande att de inte kan betraktas som en typ (ibid.).

\section{Broderier ${ }^{97}$}

I ett band behandlas utdragssömmar, det som i Hälsingland kallas för näversöm.

Zickerman beskriver näversömmen så här:

I denna är, såväl varp-som inslagstrådar - i visst antal och på lika afstånd från hvarandra - utdragna så att de bilda ett kvadratiskt rutgaller (Zickerman, del XVI, Broderi på linne, bd I).

Zickermans betoning av det visuella är typisk för hennes synsätt. Andra sätt att beskriva näversöm kommer bland annat till uttryck hos Anna-Maja Nylén som skriver om näversöm som teknik i Hemslöjd: den svenska hemslöjden fram till 1800-talets slut (1995):

\section{Hälsingland har den s. $k$. näversömmen, som är en dubbel ut- dragssöm, fått namnet av att den syddes på lärft uppspänt på näver eller enbart med trådar spända över nävret (Nylén 1995:230).}

En tredje beskrivning gör Stina Rodenstam när hon menar att näversöm är en dubbel utdragssöm som karaktäriseras av täta, stoppade mönsterpartier och av att stygnen går diagonalt (Rodenstam 1969:6). Vanligtvis sys den i vitt, ibland med rosa och blått (ibid.). Vitsen med

97. Lilli Zickerman använder beteckningen broderi, men Gertrud Grenander Nyberg föredrar att använda prydnadssöm "som beteckning för dessa alster av svensk folkkonstsömnad än termen broderi med franskt ursprung och internationell prägel" (Grenander Nyberg 1983:7). I detta kapitel används broderi som en etablerad term med betydelsen "textil metod där man med olikfärgad tråd och nål bygger upp en bild" (www.rikstermbanken.se). 


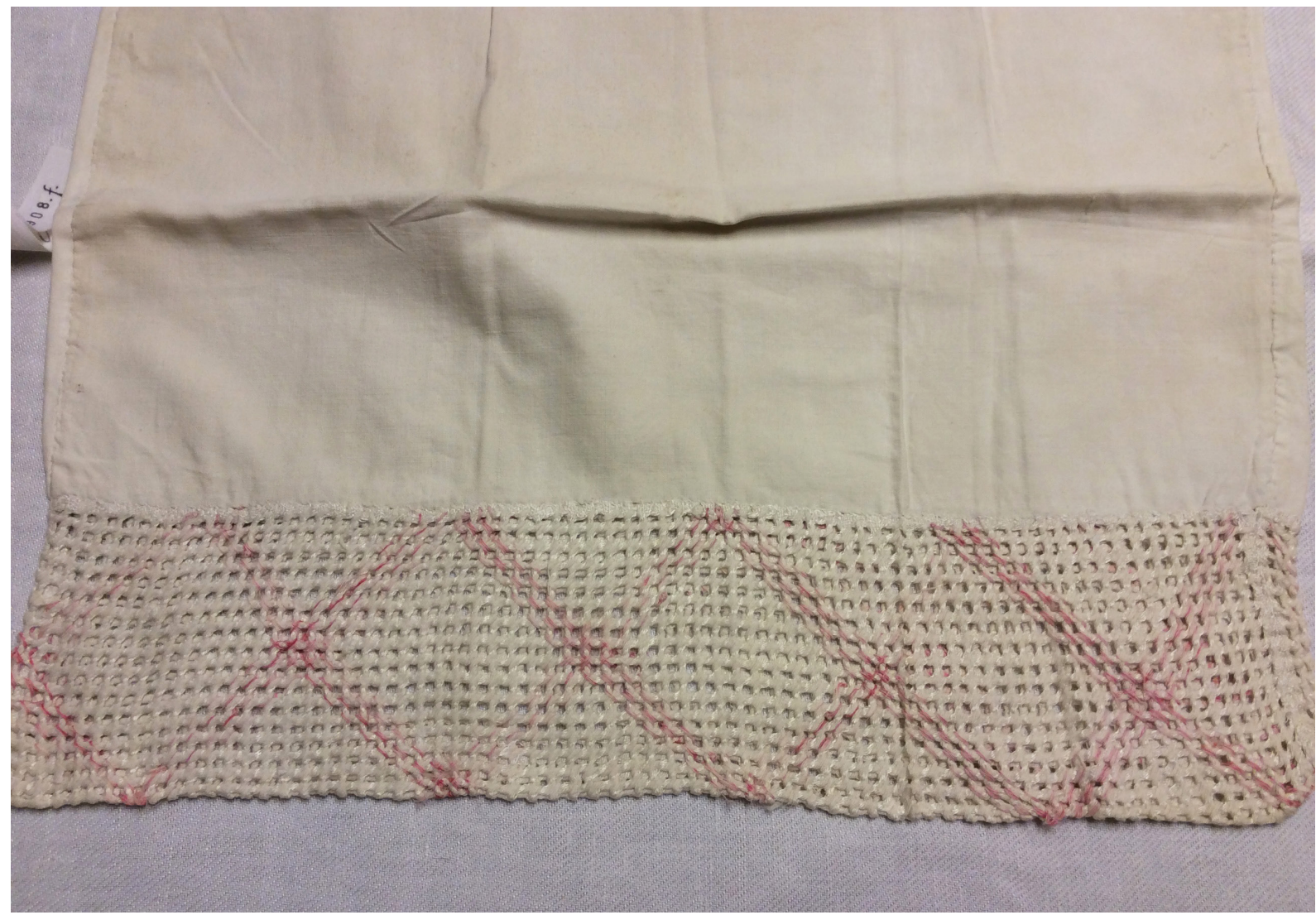

Figur 4-5 (2.7.4-5): Kuddvar/örngottshuvud kantat av näversöm med röda inslag från Järvsö hembygdsförening (XJG T 1498). Foto: Anneli Palmsköld

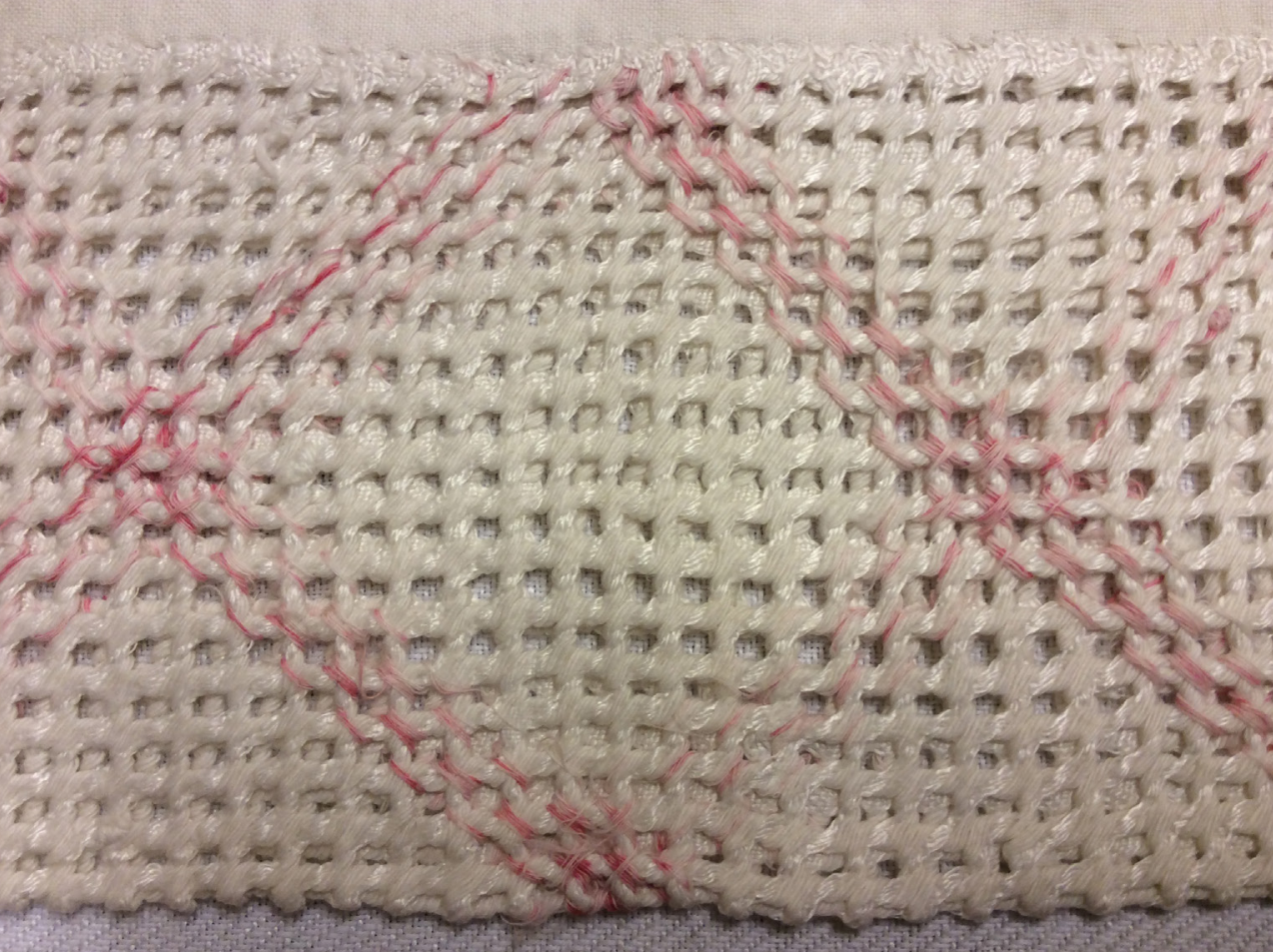


att spänna upp broderiet på lättillgänglig näver, enligt Rodenstam, var att det var transportabelt och att det tog lite plats eftersom näverbiten rullade ihop sig (ibid.). På så sätt kunde kvinnorna som var på fäbodvall eller ute i markerna ha med sig broderier och sy då tillfälle gavs (ibid.).

Greta Rodenstam, dotter till Stina Rodenstam, menar att tekniken förekom på 1700-talet, men att hur den utfördes var bortglömt i slutet av 1800-talet (Rodenstam 1969:5). Ett återupplivande skedde dock på 1890-talet genom fröken Augusta Gripenberg (1836-1925) som drev en handarbetsaffär i Hudiksvall (ibid.). Hon fick syn på ett broderat hänglakan hos sin hyresvärd, utfört i en för henne okänd teknik (ibid.), varefter hon uppmärksammade flera liknande alster (ibid.). Hon försökte hitta någon som kände till tekniken och fick veta att broderiet syddes från avigsidan och att det spändes upp på näver (ibid.). Augusta Gripenberg utvecklade tekniken och vann medaljer för sina näversömsbroderier på utställningarna i Malmö 1896, i Stockholm 1897, i Gävle 1901 och i Stockholm 1909 (ibid. 1969:6).

Själva mönstren bygger på diagonalrutans form och intentionen är, liksom i alla spetstekniker, att skapa kontraster mellan ljus och mörker, mellan täckande delar och genomsläppliga (jfr Nylén 1995:230). I Zickermans inventering framhålls att tekniken främst använts till att dekorera örngottsvar, men även till kantlister till både hänglakan och handlakan. Listerna avslutas med olika former av fransar som har sytts på i kanten. I ett av exemplen har ett örngottsvar dekorerats med ett broderi i rött, ${ }^{8}$ där mittpartiet består av en gles näversöm i rakställda rutor. Enligt Greta Rodenstam användes näversöm på hänglakan och kuddvar (Rodenstam 1969:7). I den undersökning av inredningstextilier i offentliga och privata samlingar som genomförts i forskningsprojektet, är näversöm sällsynt.

En annan broderiteknik som nämns är "korssöm", som enligt Zickerman särskilt förekommer i Delsbo socken och där "kläppformen [...] ingår såsom motiv i mönsterbildningen" (Zickerman, del XVI, Broderi på linne, bd II). I bilderna visar Zickerman hur korssömmen används för att dekorera örngottsvar, hänglakan och handlakan (ibid.). När det gäller det fria broderiet framhålls Hälsingland särskilt som "det enda landskap som visar en starkt särpräglad, bygdebetonad karaktär. Det är huvudsakligen inom Delsbo och Järvsö socknar som det egenartade

98. Fotografiet ifråga är i svartvitt, men det framgår att broderiet är i rött på vitt underlag. 


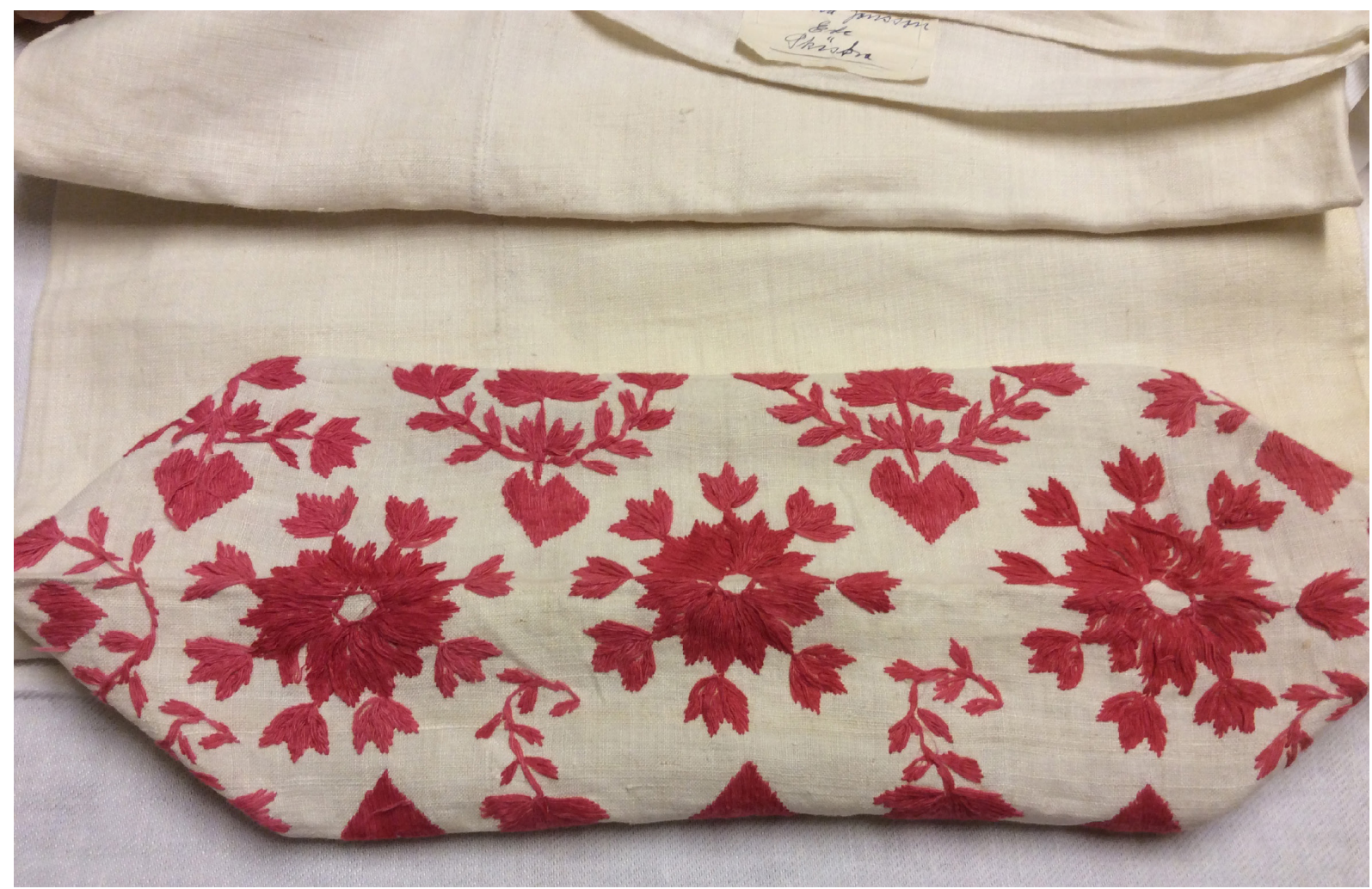

Figur 6 (2.7.6): Kuddvar/ örngottshuvud broderat med "tofssöm" i rödfärgat bomullsgarn. Järvsö hembygdsförening (XJG 908G). Foto: Anneli Palmsköld

Figur 7 (2.7.7): Kuddvar/ örngottshuvud broderat i så kallad delsbosöm. Delvis kolorerat svartvitt fotografi som ingår $i$ Lilli Zickermans studiesamling, publicerad på www.digitaltmuseum.se (HSZ.2-00109). Foto: Lilli Zickerman

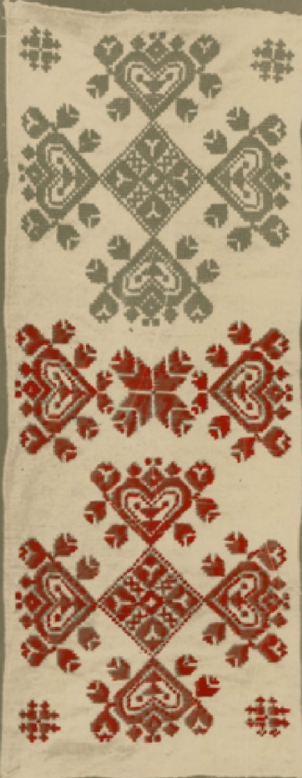


framträder" (Zickerman, del XVI, Broderi på linne, bd III). Zickerman visar exempel på örngottsvar, hänglakan och handlakan med en variation av mönsterformer i form av slingor, speglingar kring ett mittmönster, diagonalrutor med fyllningar samt även oliksidiga mönster. Enligt Brita Åsbrink och Gun Blomqvist är gränsdragningen och skillnaderna mellan broderierna i Delsbo och Järvsö inte så tydlig (Åsbrink \& Blomqvist 1970:7). De menar att Järvsösömmens mönsterformer ofta innehåller en "rikedom av tofsar som växer ut från slingor och som dekorerar och omramar stora centrala mönsterformer" (ibid.). Den benämns därför även tofssöm, ${ }^{99}$ medan delsbosömmen också kallas för långsöm (ibid.).

Broderierna från Delsbo och Järvsö har under lång tid beskrivits som ortskaraktäristiska och två exempel på "landskapssömmar", vilka "har uppstått genom att man i vissa landsändar använt sig av speciella mönsterformer, tekniker och färger på broderier" (Åsbrink \& Blomqvist 1970:7). Man har menat att mönsterformerna i dessa broderier utgörs av "förenklingar av mer komplicerade broderier" (ibid.). Idén som här uttrycks går tillbaka på det sena 1800-talets tankar om folkkonsten som "sjunket kulturgods" och härmande den konst som skapades för andra samhällsskikt, fast avsevärt mindre skickligt utförd.

Gertrud Grenander Nyberg menar i boken Lanthemmens prydnadssöm: studier av svenskt folkligt broderi på hemtextilier före 1900 (1983) att linet som producerades i Hälsingland var en förutsättning för förekomsten av broderier genom att "De släta lärfterna lämpade sig särskilt väl för prydnadssöm" (Grenander Nyberg 1983:23). Brita Åsbrink och Gun Blomqvist menar istället när det gäller Järvsösömmen att den "blev modern när den täta bomullsväven kom i handeln eftersom den var svår att räkna trådar på, så som man gjorde på de äldre materialbundna sömsätten” (Åsbrink \& Blomqvist 1970:7). Oavsett om lin, halvbomull eller bomull användes som underlag, var det viktigt att det var lätt och följsamt att hantera i hantverksprocessen så att synålar utan alltför mycket besvär kunde stickas igenom tyget och att stygnen lade sig fint intill varandra. En annan anledning till val av underlag kan vara att den ljusa bakgrunden lyfte fram mönstren som bildades av det färgade - oftast röda - garnet. Broderiet kunde te sig mycket kontrastrikt (se fig. 12-21).

99. De alternativa benämningarna "tofssöm", "tafssöm" och "Jervsösöm" förekommer på ett katalogkort över ett broderat kuddvar, insamlat 1915 till Nordiska museet av Emilie von Walterstorff (NM 125706). 


\section{Flätningar och spetsar}

Hänglakan och handlakan avslutas ofta med fransar eller flätningar. I Zickermans inventering redovisas textilier från Hälsingland med flätningar med fyra lockar (Zickerman, del XV I I I, Flätning, bd III). Symmetrin som skapas när flätningen sker med fyrtalet som utgångspunkt, ger en helt annan mönsterbild än när flätning sker med tre grupper av trådar (se Palmsköld 2007). Mönstren på Zickermans bilder är lätta och skira till sin karaktär med många mellanrum och tunna bryggor som förbinder större mönsterformer som romber, trianglar och viggmönster men även med tätare och glesare tvärränder. Flätningar förekommer mycket sparsmakat i undersökningen som har genomförts i forskningsprojektet. Det är inte enda exemplet på diskrepansen mellan Zickermans urval och det faktiska bevarade av föremålsbeståndet.

När det gäller knyppling nämns Bollnäs som ett viktigt centrum med rikast och mest omväxlande mönster (Zickerman, del XIX, Knyppling, bd II). En annan viktig plats i sammanhanget är Delsbo socken, där spetsarna karaktäriseras som utförda i grovt rött och vitt bomullsgarn och mönstrade med rutor, hjärtan och mandlar (ibid.). Enligt Zickerman knypplade befolkningen här för avsalu och spetsarna från Delsbo förekom därför i angränsande socknar (ibid.). Ett flertal av de spetsar som redovisas i bildmaterialet är omonterade, andra är fastsydda på hänglakan och handkläden och ytterligare några har monterats som dekor på örngottsvar.

Det är värt att notera att Stina Rodenstam ${ }^{100} 1912$ skänkte en samling knypplade spetsprover från Delsbo socken omfattande 17 olika mönster till Nordiska museet (NM 117314a-p). Samlingen består av omonterade spetsar av varierande bredd och komplexitet i mönsterformerna. De knypplade spetsar som förekommer i undersökningen av inredningstextilier i offentliga och privata samlingar, stämmer överens med Lilli Zickermans beskrivning.

Ytterligare en spetsteknik som Zickerman tar upp är knytning och trädning som förekommer på handkläden, men även som dekor på örngottsvar (Zickerman, del XX, Knytning). Tekniken innebär att ett nätverk av kvadratiska rutor knyts. Rutorna kan vara horisontella eller rombformiga. Mönster skapas genom att trådar träs och packas tätt så att täta partier bildas. Konturer kan också skapas kring mönsterformerna. I bildmaterialet förekommer mönster i form av romber, hjärtan,

100. Om Stina Rodenstam, se Danielson 1986. 


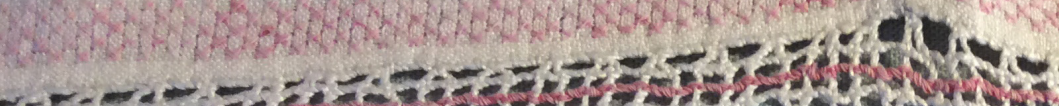

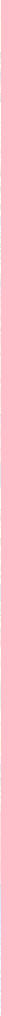

kors, triangelformer, halva och hela stjärnmönster samt viggar. Ofta är mönstren rikliga och tätt liggande, ibland betydligt glesare så att det knutna nätet dominerar. Av bilderna framgår att trädningen främst har utförts i ljust garn, men att även rött garn förekommer. Det röda garnet användes också till konturer.

\section{Användning av färger}

Bakom varje textil låg ett omfattande arbete för att framställa material, där inte minst färgerna var viktiga för slutresultatet genom att de användes för att skapa dekorationer, mönster och variationer. Hur hantverkarna fick tag på sitt material, och hur det färgades in, framgår inte av de uppgifter som finns om de enskilda textilierna. Det kan förekomma uppgifter på museers katalogkort om enskilda föremål, som till exempel beskrivningen av en rya i Nordiska museets samlingar (NM 122709). Ryan är avbildad i sin helhet i akvarell och i texten
Figur 8 (2.7.8):

Detalj av hänglakan med broderier i korssöm och kant av knypplad Delsbospets i vitt och med rött bomullsgarn. Monogramdaterad "IBID 1832". Ägs av Delsbo hembygds- och fornminnesförening (XD 2763). Foto: Anneli Palmsköld 
talas det om att bresilja har använts för att färga in garnet $i$ varpen. Forskning om historiska färgmetoder är dessutom knapphändig (Olars 2015:3f).

Även om färgning var en professionell verksamhet (se Bergström 2013; Palmsköld \& Fabler 2018), var hemfärgning på ull vanlig med växter som lavar och löv hämtade från naturen (se Olars 2015:26f). Den viktigaste egenskapen var färgens hållbarhet, den "måste hålla lika länge som det material den sitter på” (Runefelt 2015:111). Vilka procedurer som hela färgningsprocessen innehöll och vilka färggivande växter som användes, är frågor som inte står i fokus för denna undersökning. Det empiriska materialet innehåller dock exempel på flertalet färger. En rya från Stocksäter i Bollnäs socken som finns i Nordiska museets samlingar, har till exempel enligt uppgift mönstrats med "grönt, blått, gult, rött, gulrosa o vitt ullgarn" (NM 204685). En dyna från Trönö socken insamlad genom Artur Hazelius 1873, beskrivs enligt följande: "Mönster i krabbasnår af ylle i brunt, blått och grönt. [...] I hörnen tofsar af röda och blå ylleremsor" (NM 2995). Ytterligare en rya från Alfta socken har "mörkbrun botten med rutmönster i flera färger, klart blått, grönt och vitt och något rött" (EU 2214).

Färgerna som nämns här förekommer även i de inredningstextilier som har ingått i undersökningen. De stämmer också med resultatet av Katarina Olars undersökning av vilka färgämnen som användes i Hälsinglands inredningskultur där hon genom arkivstudier av färgerier och receptböcker kan se att det rör sig om röda, blå, gula, gröna, svarta och grå samt bruna färger (Olars 2015). I det följande kommer särskilt de röda och blå färgerna att fokuseras, baserat på resultaten av delstudier som har genomförts i forskningsprojektet (Palmsköld \& Fabler 2018; Nyström et al. 2016; Nyström \& Roxvall 2018).

\section{Turkrött bomullsgarn}

En viktig nyhet som fick stort genomslag under den tidsperiod som här undersöks är det turkröda bomullsgarnet, där kulören kunde skifta från ljust rosa till starkt och fylligt rött. I arkivmaterial efter bonden Olof Persson (1793-1858) i Fågelsjö socken, Hälsingland, finns kvittenser från ortens handelsbod över varor som han inhandlade. På ett odaterat kvitto står det att han "bekommit följande varor $1 / 2$ lod rödt turkiskt garn 16" (Olof Perssons arkiv). Det betyder att turkrött bomullsgarn fanns tillgängligt och gick att köpa lokalt. Enligt uppgift från Stina Rodenstam kunde även en lokal skicklig färgerska anlitas och då använ- 
des importerad koschenill för att få rätt högröd färgnyans (Rodenstam 1986:12). Detta är exempel på hur det turkröda bomullsgarnet i mitten av 1800-talet kom att bli tillgängligt för brodöser, spetsknypplerskor och väverskor i Hälsingland. Dess popularitet framträder i Zickermans Sveriges folkliga textilkonst liksom i bevarade textilier, där den röda färgen bildar tydliga och skarpa mönster mot en vit botten i linne, halvbomull eller bomull. Berit Eldvik har i sin undersökning av broderier från Järvsö, pekat på hur tillgången till bomull och turkrött bomullsgarn medverkade till en omfattande ökning av antalet broderier i mitten av 1800-talet (Eldvik \& Åsbrink 1979:60). De tidigast daterade broderierna i Eldviks undersökning är från 1831 och $1837^{101}$ och utfört på bomull som sytts fast på ett örngott av linne (ibid. 1979:60). Bomull förknippades med hög status och därför användes det sparsmakat och bara där det syntes, som till exempel på hänglakan och kuddvar i sängarnas utrustning (ibid. 1979:59f). Färgen uppskattades särskilt på grund av sin hållbarhet (ibid. 1979:61).

Bomullen fortsatte att ersätta linet under 1840-talet och textilier tillverkade enbart i bomull alternativt i hälften bomull och hälften lin förekom på 1850-talet (ibid.). Dessa decennier i mitten av 1800-talet var en viktig period av stora förändringar i textilhistoriskt hänseende. I ett europeiskt perspektiv sammanfaller detta med perioden 1750-1850, som har kallats för "the painted cotton craze" (Martinsen 2001). Då fanns det en stor efterfrågan på tryckta bomullstextilier i klara och starka kulörer, men även på färgat bomullsgarn. Enligt uppgiftslämnare i Eldviks studie, köptes det turkröda bomullsgarnet i handelsbodar eller på marknader (Eldvik 1977). Varifrån det hämtades till handelsbodar och marknader framgår inte. En teori är att knallarna kan ha medverkat till spridning av det rödfärgade garnet (ibid.) och det anses sannolikt ha varit importerat från Tyskland eller Skottland. ${ }^{102}$

I Hälsingland förekommer även vävnader som vittnar om den turkröda färgens popularitet. Ett exempel är de huvor och handkläden som har prytts med rött mönster vävt i enkel rosengång ( $\mathrm{LjM}_{4232}$, XJG T 1490). De är vävda i tunt garn, som kräver många inslag för att packas

101. I forskningsprojektet är det äldsta daterade broderiet från 1821. Det rör sig om ett kuddvar/örngottshuvud med broderier i rött och med monogrammet "BAD" som ägs av Järvsö hembygdsförening (utan märkning).

102. För en utförligare beskrivning av hur turkisk rödfärgning började praktiseras i Sverige, se Palmsköld \& Fabler 2018. 
(jfr Eldvik \& Åsbrink 1979). Den röda kulören är intensiv och framträder starkt tillsammans med kritvitt bomullsgarn. Andra exempel på tekniker där turkrött bomullsgarn förekommer är i knypplade och virkade spetsar samt i olika typer av fransar som kunde pryda örngottshuvor, handkläden och hänglakan. Den röda färgen användes här sparsmakat och strategiskt som dekoration och mönster mot det dominerande vita bomullsgarnet.

Den så kallade turkröda färgen kom att bli vanlig och uppskattad för dem som tillverkade textilier i olika tekniker. Under en period var detta den metod som användes för att färga in bomull i röda till rosa nyanser. När anilinfärgerna introducerades och började säljas i påsar till allmänheten för hemfärgning, kom den turkiskt röda infärgningsmetoden att fasas ut snabbast av växtfärgningsmetoderna.

\section{Blå färg av indigo och vejde}

Om den röda färgen främst användes för broderier, förekommer den blå färgen i vävnader som framställdes för inredning och beklädnad. Med den turkröda metoden gick det att färga in bomull, men det gick att åstadkomma blå nyanser på både ull- och cellulosamaterial (Olars 2015:27). På så sätt hade den blå färgen en bredare användning.

Kring sekelskiftet 1700 började de ostindiska kompanierna importera indigo (exotisk indigo) för att framställa blå färg (Olars 2015). Innan dess användes främst vejde och under en period användes båda ämnena vid färgning. När textilier färgades in kunde även blå pigment till måleri framställas (Nyström et al. 2016), som sedan bland annat såldes till de målare som var verksamma i Hälsingland. ${ }^{103}$

Det fanns andra sätt att färga in textilier i blått utöver indigo och vejde (Isatis tinctoria) som med hjälp av blå bresilja, färgarpilört och blåa bär (Sandberg \& Sisefsky 1981:78). Olars menar dock att i stort sett användes antingen indigo eller blå bresilja (Olars 2015:27). Det är svårt att med säkerhet säga i vilken omfattning hushållen färgade själva och vad som utfördes av professionella färgare.

I en delstudie i forskningsprojektet ställdes frågan om det är möjligt att med hjälp av Raman-spektroskopi undersöka blåfärgade textilier för att avgöra om de har färgats in med exotisk indigo eller vejde (Nyström et al. 2016). Referenser framställda efter historiska recept jämfördes med trådar från en kjol vävd i blåfärgad ull från Delsbo socken samt

103. Hur processen gick till beskrivs närmare i Nyström et al. 2016. 
från tre nystan av olika blåfärgade trasor i bomull på gården Bortom Åa, förberedda för att användas i vävning av bland annat slarvtäcken. Resultatet av studien visar att trådarna från kjolen troligtvis är infärgade med exotisk indigo, men att det är svårare att fastställa vilket pigment som har använts för att färga in trådarna från bomullstrasorna. Detta kan bero på att materialet är väl använt och tvättat, innan det har klippts sönder till trasor.

Vad användes då den blå färgen till i inredningstextilierna i Hälsingland? I inventeringsmaterialet finns exempel på hur bitar av blåfärgade textilier vävdes in i så kallade slarvtäcken, som prydde sängarna i inredningen. Det handlar om de textilier som Lilli Zickerman i sin inventering benämnde linnebottentäcken. Täckena är alltså i huvudsak vävda i linne, med inslag av remsor som har klippts av avlagda och slitna linnetyger samt varp av lingarn. Bottnarna är ljusa med ränder i avvikande färger, ofta förekommer blå färger. Mellan de randade partierna har bitar av tyger i skilda färger plockats in så att de bildar mönsterformer som rundlar, sneda streck eller sicksack-vågor. I ett slarvtäcke som ägs av Järvsö hembygdsförening förekommer mönsterfärger som svart och olika nyanser av grönt, rött och blått. De blåfärgade remsorna är påtagligt lika de trasnystan som undersöktes ovan. Vid en närmare undersökning av de inplockade tygremsorna går det att identifiera inslag av stickade bitar, rosengångsvävnader, något som kan vara en rest av en kyrkvante med broderier i silke, förklädestyg, rocktyg, kjoltyg samt långrocksfoder.

Blå färg förekommer även på vävda mattor. Ett exempel är en långrandig matta som finns i samlingarna på Hälsinglands museum i Hudiksvall och som är vävd i spetskypert i bomull i färgerna rött, vitt och två olika blå nyanser (HM 8734). I mattans ytterkanter finns en bred röd bård med infällda ränder i vad som ser ut att vara ikatfärgat garn i blått på vitt. Blå färg förekommer sällan på hänglakan, men i ett fall förekommer en diskret inslagsrand med ikatfärgat garn i blått på vitt (XJG 103) (se fig. 11). På den vita textilen dominerar röda ränder och monogrammet "EED 1844", det blå syns mycket svagt i en vit rand. Rester av trådar i nederkanten indikerar att något tidigare har varit fastsytt, kanske en spets.

Även i hälsingska ryor förekommer blå färger. I Sveriges folkliga textilkonst nämner Lilli Zickerman att blå färg användes tillsammans med rött, grönt och vitt (del XI, Flossa, bd III). Ryorna illustreras i akvareller. Förutom mönstren åskådliggörs färgerna som ingår i målade 


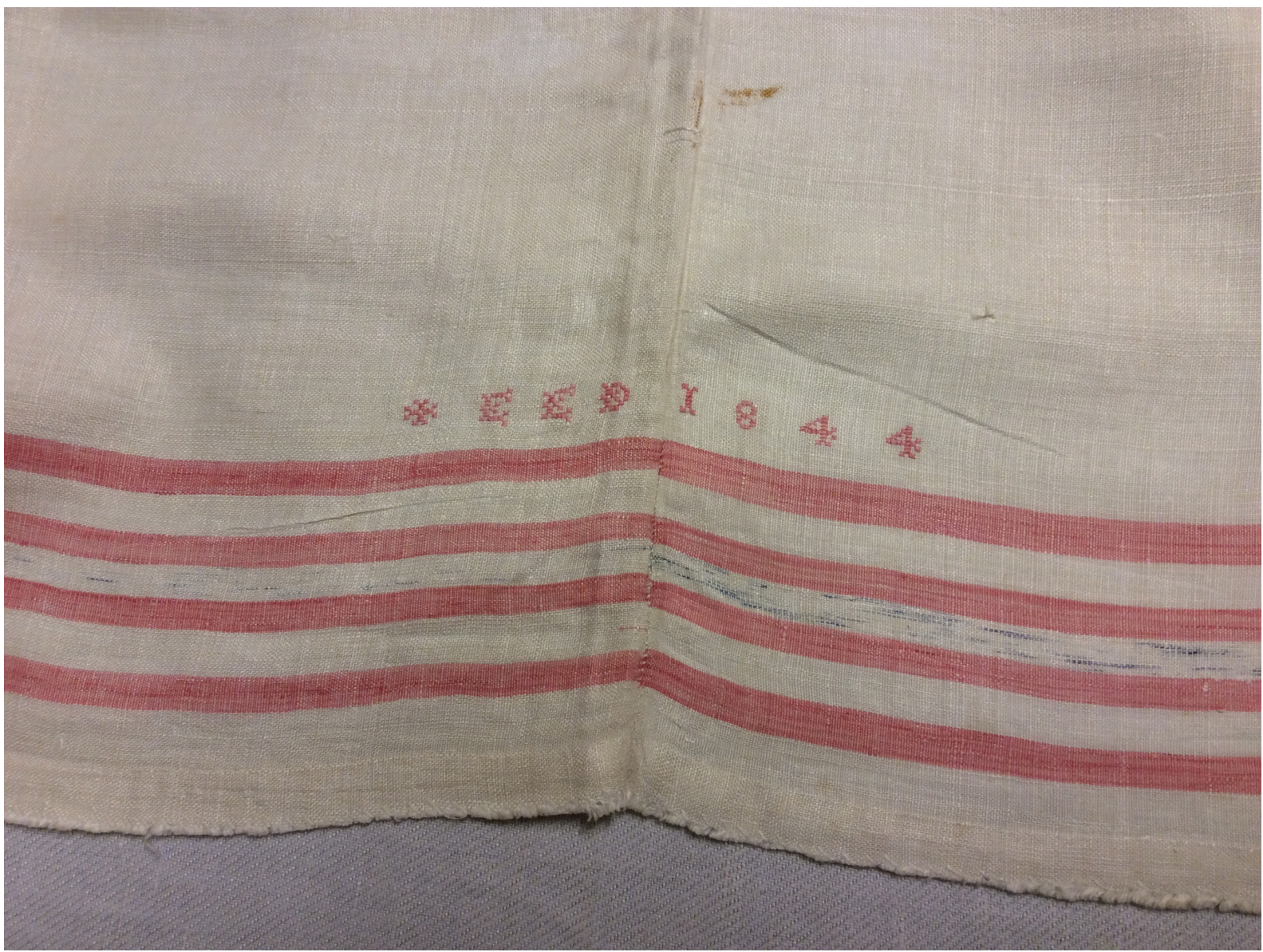

kvadrater. Vanliga färgkombinationer är blått, grönt, rött, svart, brunt och gult.

Färger och deras framställning var en viktig fråga för Lilli Zickerman, kretsen kring henne men även henne efterföljare. ${ }^{104}$ Gerda Boëthius, professor i konsthistoria och grundare av och redaktör för tidningen Hemslöjd 1933-1959, tog upp frågan i sina texter. I en odaterad artikel rubricerad Hemslöjden, skriver hon om dess ortskaraktär med utgångspunkt från den lokala florans betydelse för färgskalan i en trakt (Boëthius u.å.:456). Hon menar att tillgången på andra färgämnen har påverkat uttrycket och lyfter fram att utseendet och kvaliteten på linet påverkas av hur det rötas, liksom ullen av fårraser och avelsarbete (ibid.). Tillsammans med faktorer som val av teknik, garnets kvalitet, "impulser utifrån" och kända mönster skapades särskilda stilar som var typiska för olika orter, menar Boëthius (ibid. u.å.:457). Hon pekar här

Figur 11 (2.7.11): Hänglakanet är mönstrat med röda ränder och monogram med årtal. I ett av de ljusa partierna har ikatfärgat inslagsgarn använts och små blå strimmor framträder. Ägs av Järvsö hembygdsförening (XJG 103). Foto: Anneli Palmsköld

104. Om hur kunskaper om växtfärgning och recept lärdes ut och spreds i början av 1900-talet, se Thomasson 2015. 
på komplexiteten i hantverkarens kunskaper, att det inte bara handlade om själva görandet utan även om hur lokala omständigheter påverkar material och färger (jfr Olars 2015:4).

\section{Betydelsen av mönster}

Folkkonstens mönster och dekorer brukar karaktäriseras av ytbundenhet, repetitiva, geometriska inslag och stiliseringar av mönster och motiv. Därtill en komposition där dekoren fördelas över den yta som står till buds, gärna symmetriskt utifrån en tänkt mittlinje. Karaktäristiken har i första hand använts för att beskriva och analysera måleri, inte textilier. Eftersom textilier bildas genom att trådar transformeras till ytor, kan den textila folkkonsten av tekniska skäl beskrivas som ytbunden. Men den är även ytbunden genom det sätt som mönsterformerna har komponerats. Mönster och dekorer bygger ofta på repetitioner och symmetrier där mönsterpartier kan likna varandra kompositionsmässigt, men även på att mönster spegelvänds (speglas). Exempel på detta finns både på vävda täcken och broderier där mönster har placerats utifrån en mittlinje som kan gå både vertikalt och horisontellt. I de fall mänskliga gestalter har formats, kan symmetrierna bygga på att likartade, men inte exakta former har skapats som till exempel en mans- och en kvinnofigur. Det behöver alltså inte handla om en upprepning av exakt likadana mönsterformer. Repetitionerna kan också bygga på att samma mönsterform återkommer över en yta. En annan typ av komposition är den där ytan har täckts av ett galler som ramar in mönsterformer. Vissa mönster är liksidiga och saknar riktning, andra är tydliga i sina riktningar och tänkta att betraktas från ett specifikt håll. I det följande visas en serie med exempel på mönsterbildningar i broderier med kommentarer i bildtexterna.

En mycket stor del av den folkliga textilkonsten, även utanför Hälsingland, bygger på geometriska och icke föreställande mönster och dekorer (se t.ex. Palmsköld 2007). Därför är det svårt att hävda att avsikten har varit att stilisera. Själva ordet antyder implicit att det finns ett verklighetstroget sätt att avbilda något och att folkkonstnären istället framställer motivet på ett förenklat, stiliserat eller abstraherat sätt. Detta kan enligt detta sätt att resonera, göras antigen medvetet eller oreflekterat men också på grund av okunskap. Beroende på vilken utgångspunkt det handlar om kan resultatet definieras som mer eller mindre avancerat.

Ett annat sätt att tala om estetiska möjligheter när det gäller textil 


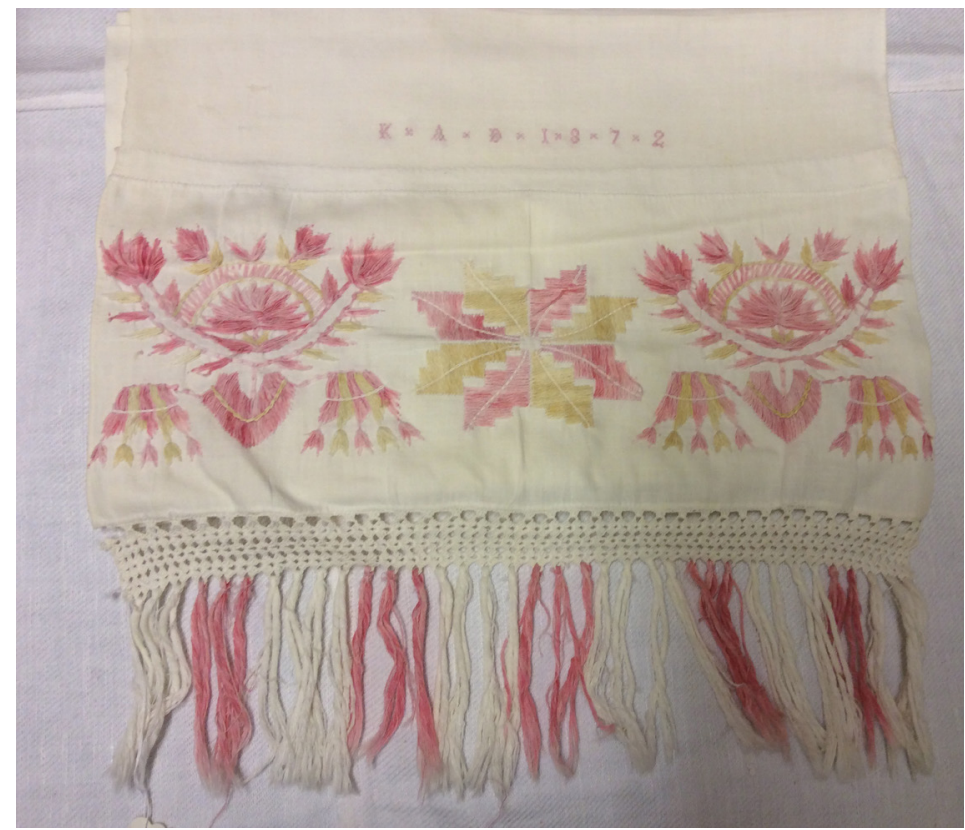

Figur 12 (2.7.12): Handkläde med monogram "KAD 1872". Påsytt broderi i rött och gult samt påsydd virkad spets och knuten frans i rött och vitt. Broderiet är komponerat utifrån ett stjärnformat mittmönster utan riktning, där röda former blandas med gula. På vardera sida speglas två likadana mönsterformer som har en tydlig riktning, med en lite tyngre form som pekar uppåt och en lättare form som pekar nedåt. Ägs av Järvsö hembygdsförening (utan märkning). Foto: Anneli Palmsköld

Figur 13 (2.7.13): Kuddvar/örngottshuvud med broderat monogram "BPD". Broderiet som är sytt på kuddvaret består av tre likadana mönsterformer utan riktning som enligt uppgift i Järvsö hembygdsförening ska ses som kvarnformer eller kronbrudar. Mellan de tre formerna har mindre mönster i korsstygn respektive plattsöm placerats. Vid en närmare granskning är de fyra formerna som är förgrenade varianter på samma tema, även om de vid en snabb blick ser likadana ut. Ägs av Järvsö hembygdsförening (XJC T 1489). Foto: Anneli Palmsköld

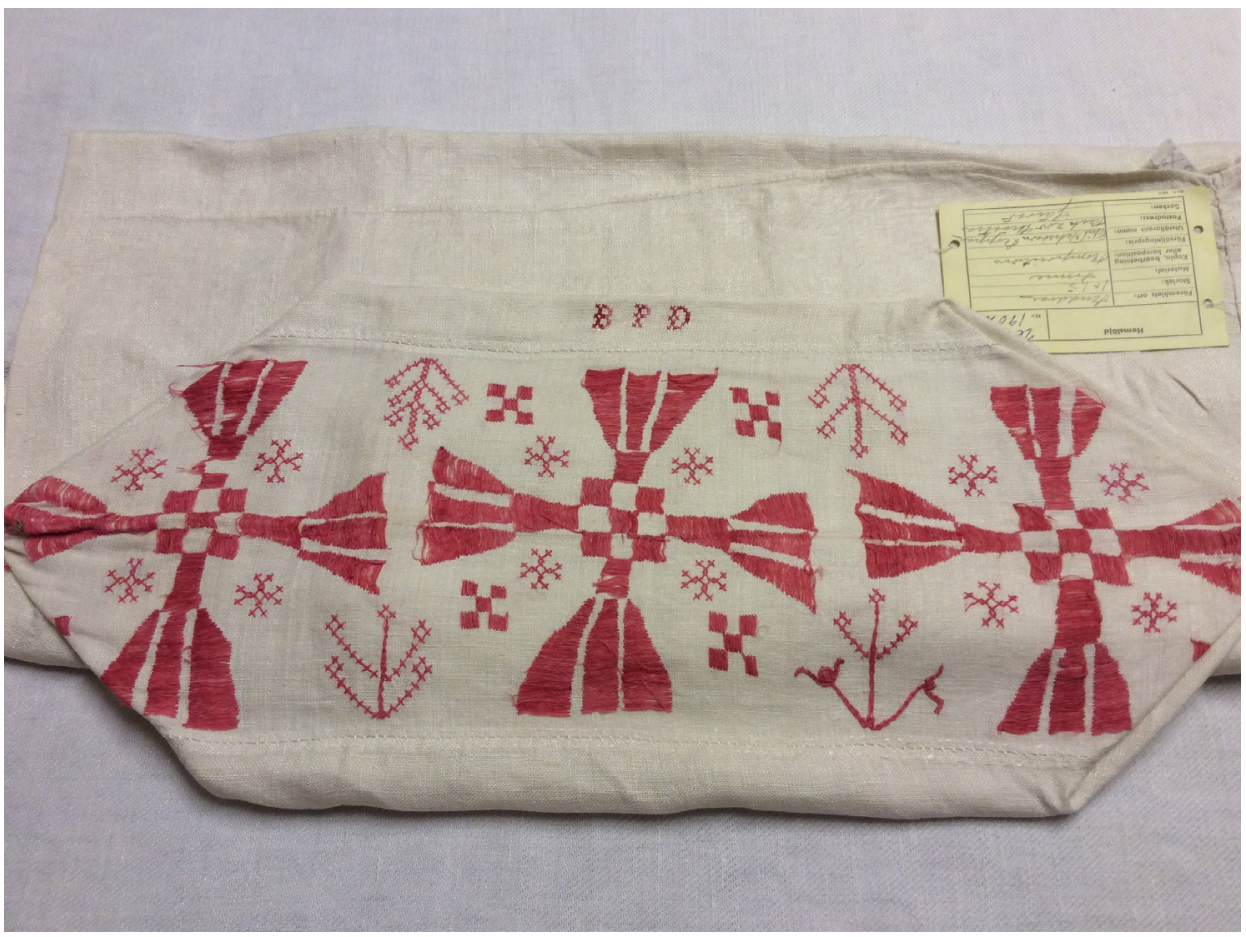




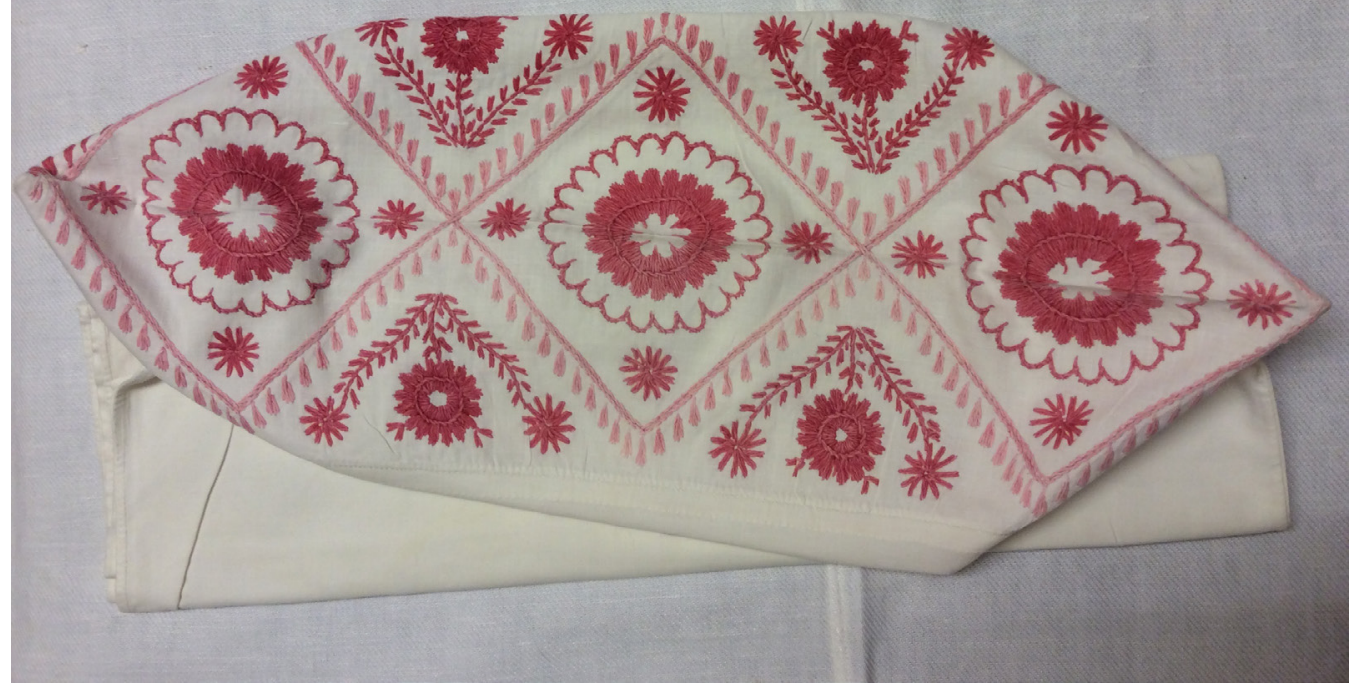

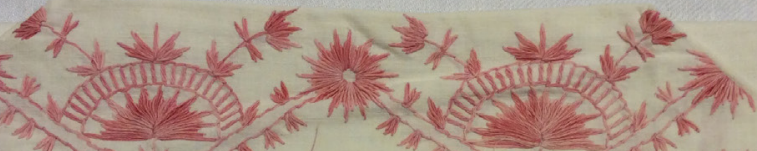

a

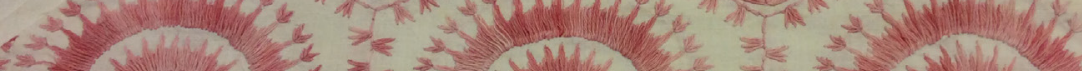

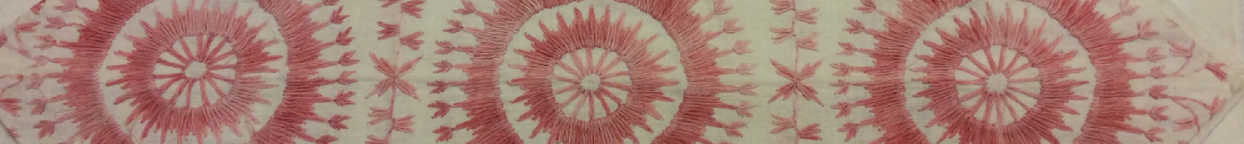

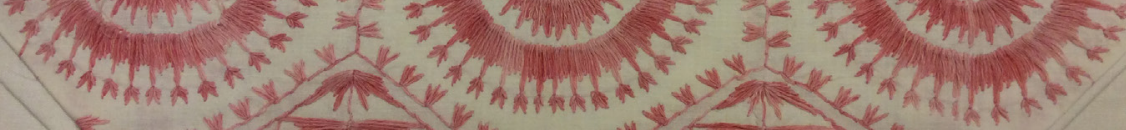

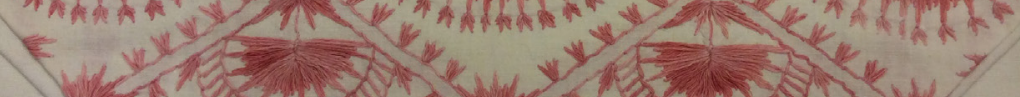

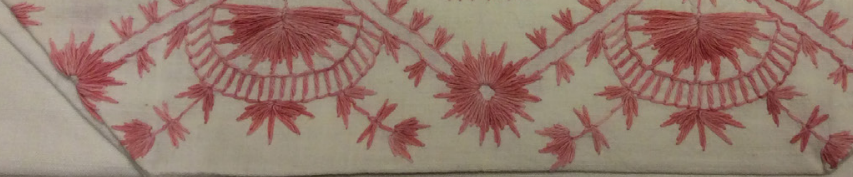

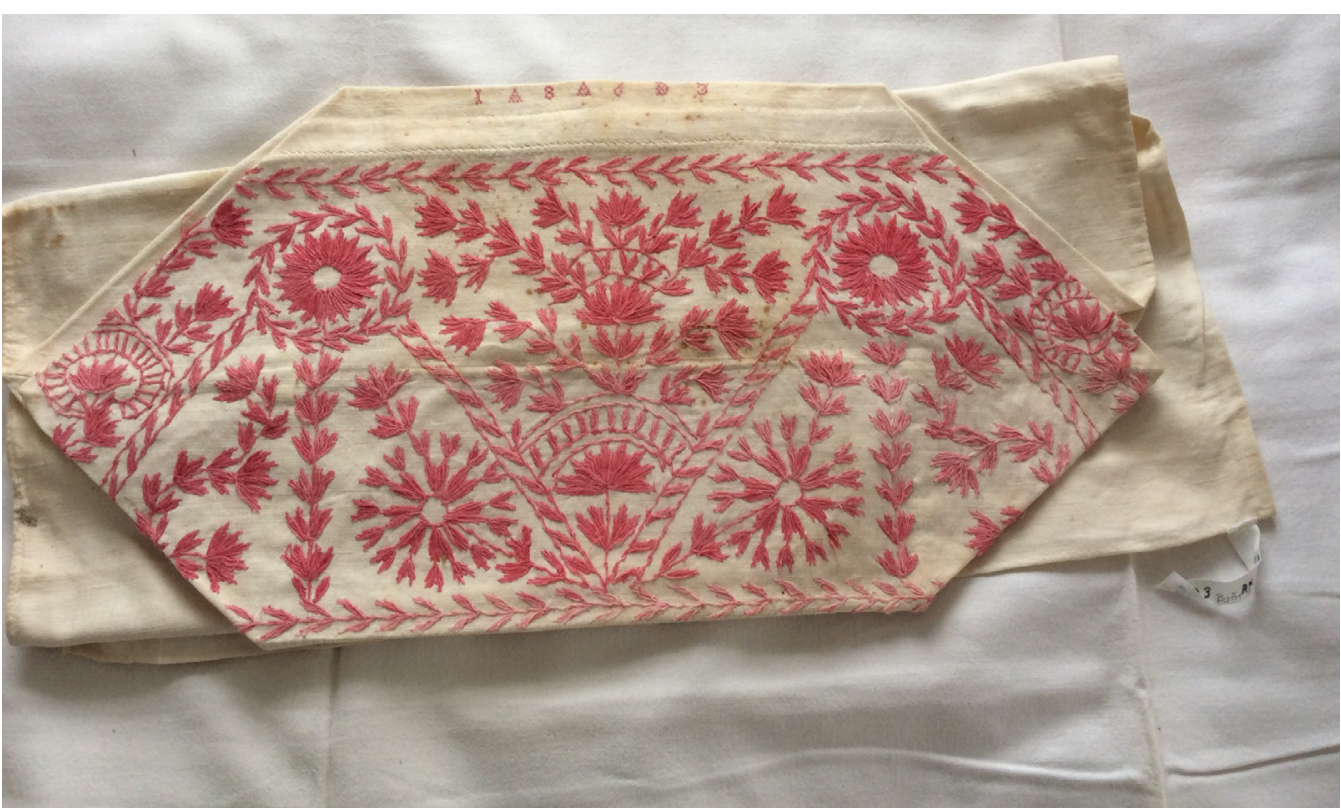


\Figur 14 (2.7.14): Kuddvar/örngottshuvud med broderier i rött och rosa. Broderiet består av tre likadana runda mönsterformer på rad, placerade i ett rektangulärt galler och med fyra blomsterformer i mellanrummen. Dessa är komponerade inom en triangelform, med tre stjälkar som avslutas med runda blomformer. Ägs av Järvsö hembygdsförening (utan märkning). Foto: Anneli Palmsköld

$\leftarrow$ Figur 15 (2.7.15): Kuddvar/örngottshuvud med broderier i rött. Kompositionen liknar den som syns ovan, men här ramas de rundade formerna in i ett oktangulärt galler. I mötespunkterna har brodösen placerat runda former som strålar ut samt tofsliknande former. Ägs av Järvsö hembygdsförening (utan märkning). Foto: Anneli Palmsköld

$\checkmark$ Figur 16 (2.7.16): Kuddvar/örngottshuvud med broderier i rött och monogram som blandar siffrorna i årtalet med ägarens initialer: "1A8A6D3". På långsidorna av den broderade ytan ramas mönstret in av en ranka där förgreningarna ("tofsarna") pekar åt ett håll på den övre och ett annat på den nedre rankan. I mitten av den nedre rankan börjar ett korgformat mönster som ramas in av viggar som möts i rundlar. Ytorna är fyllda av rundlar, rankor och tofsliknande former. Hela mönstret har en riktning, ett upp och ett ned, även om det speglar sig kring en mittlinje. I privat ägo. Foto: Anneli Palmsköld

$\downarrow$ Figur 17 (2.7.17): Kuddvar/örngottshuvud med broderier i rött. Här har det vita bottentyget översållats med stjärnor i olika storlekar broderade i plattsöm. I de vågräta raderna är stjärnorna omväxlande små och stora, i de lodräta raderna är de lika stora. Ägs av Järvsö hembygdsförening (XJG 100). Foto: Anneli Palmsköld

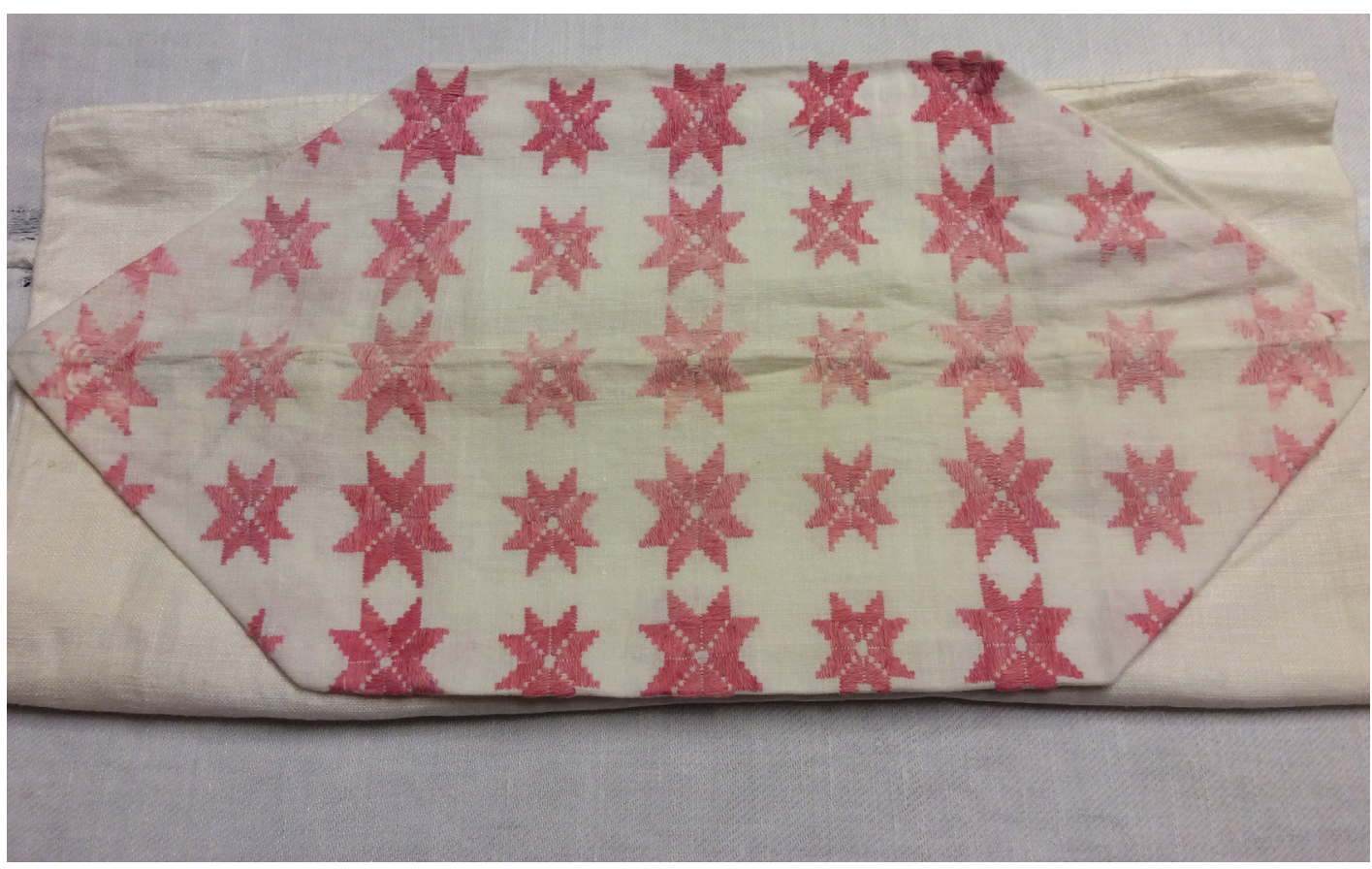



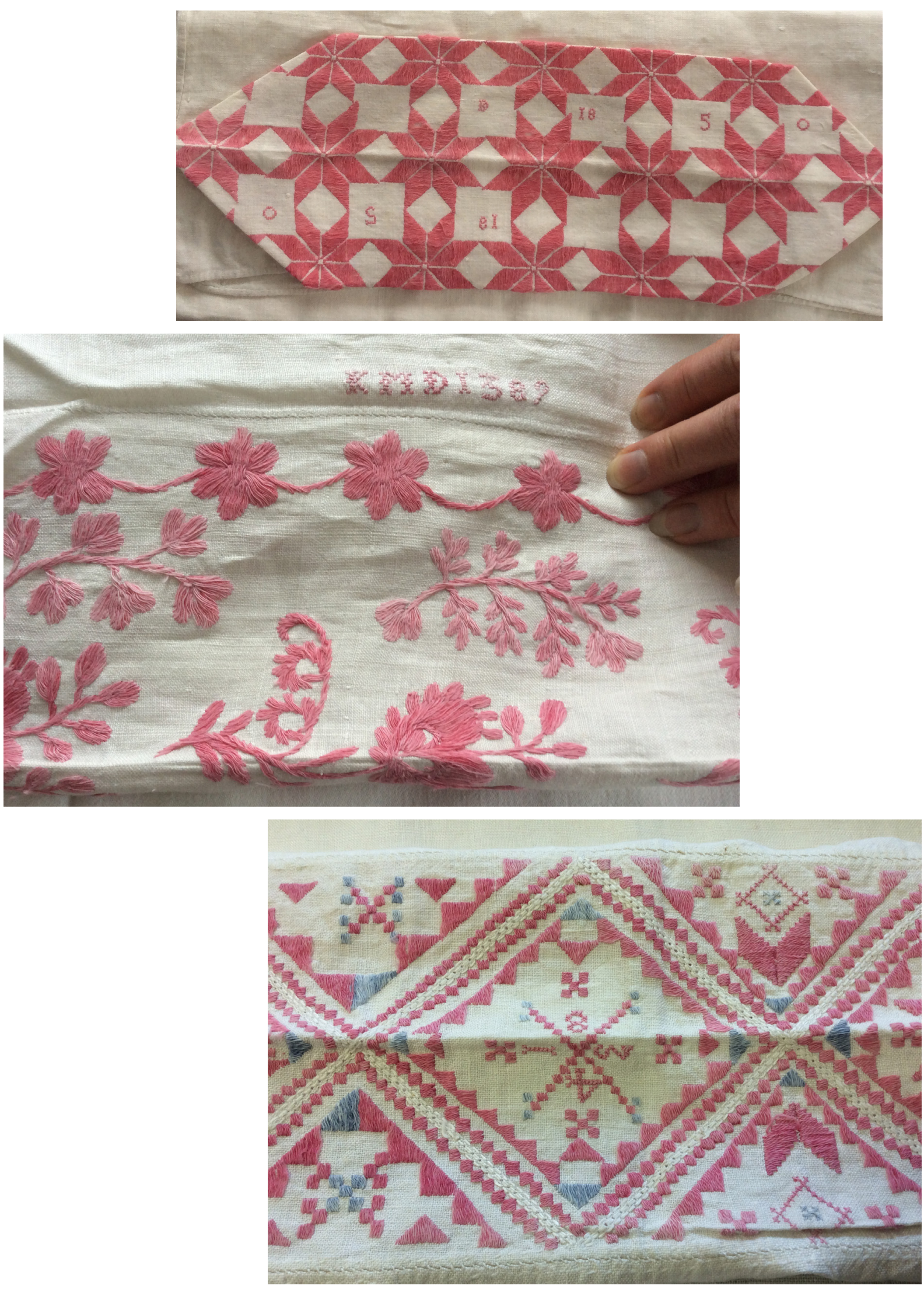
\Figur 18 (2.7.18): Kuddvar/örngottshuvud med broderier i rött. Broderiet är även här översållat av stjärnor utförda i plattsöm. Skillnaden är att de är lika stora och att de har rakare och skarpare linjer. Spetsarna på stjärnorna är menade att möta varandra, men så är inte alltid fallet. I de vita rutorna som bottenväven bildar har bokstaven "D" och årtalet "1850" broderats i korsstygn. Årtalet förekommer två gånger så att det kan läsas från två håll. Det är placerat utifrån en mittlinje som delar av de sex rutorna och därför är årtalet uppdelat så att det står "18" i rutorna närmast mitten, följt av "5" och "0". I privat ägo.

Foto: Anneli Palmsköld

—Figur 19 (2.7.19): Detalj av broderi i rött på ett kuddvar/örngottshuvud. På bilden syns hur tätt vävd bottenväven är som utgör grunden för broderiet. I detta fall är stygnen långa och på sina ställen lite spretiga. I monogrammet har brodösen vänt på siffrorna i årtalet, så att det står "KMD 1389". I privat ägo. Foto: Anneli Palmsköld

$\measuredangle$ Figur 20 (2.7.20): Detalj av broderi i rött, blått och vitt på ett kuddvar/örngottshuvud. Mönstret är strikt geometriskt vilket understryks av att brodösen har använt sig av bundna sömnadssätt. Det bygger på snedställda rektanglar som ramar in mönsterformer. I mitten står årtalet "1834", där siffrorna har placerats runt en mittpunkt så att de kan läsas från flera håll. Även om den röda färgen dominerar, har den vita använts för att understryka linjerna i de rektangulära formerna. Den blå färgen har använts utspritt och strategiskt för att variera mönsterbilden. Ägs av Hälsinglands museum, med proveniens Bjuråker (HM 25653). Foto: Anneli Palmsköld

$\downarrow$ Figur 21 (2.7.21): Detalj av handkläde med broderi i rött och monogram med årtal samt en avslutande frans i rött och vitt. Här är broderiet utfört i korsstygn med glest placerade solitära mönsterformer, med små broderade rutmönster emellan. Mönstret är oliksidigt och har en tydlig riktning. Ägs av Delsbo hembygdsförening och ingår i Märta Brodéns samling (XD 2546). Foto: Anneli Palmsköld

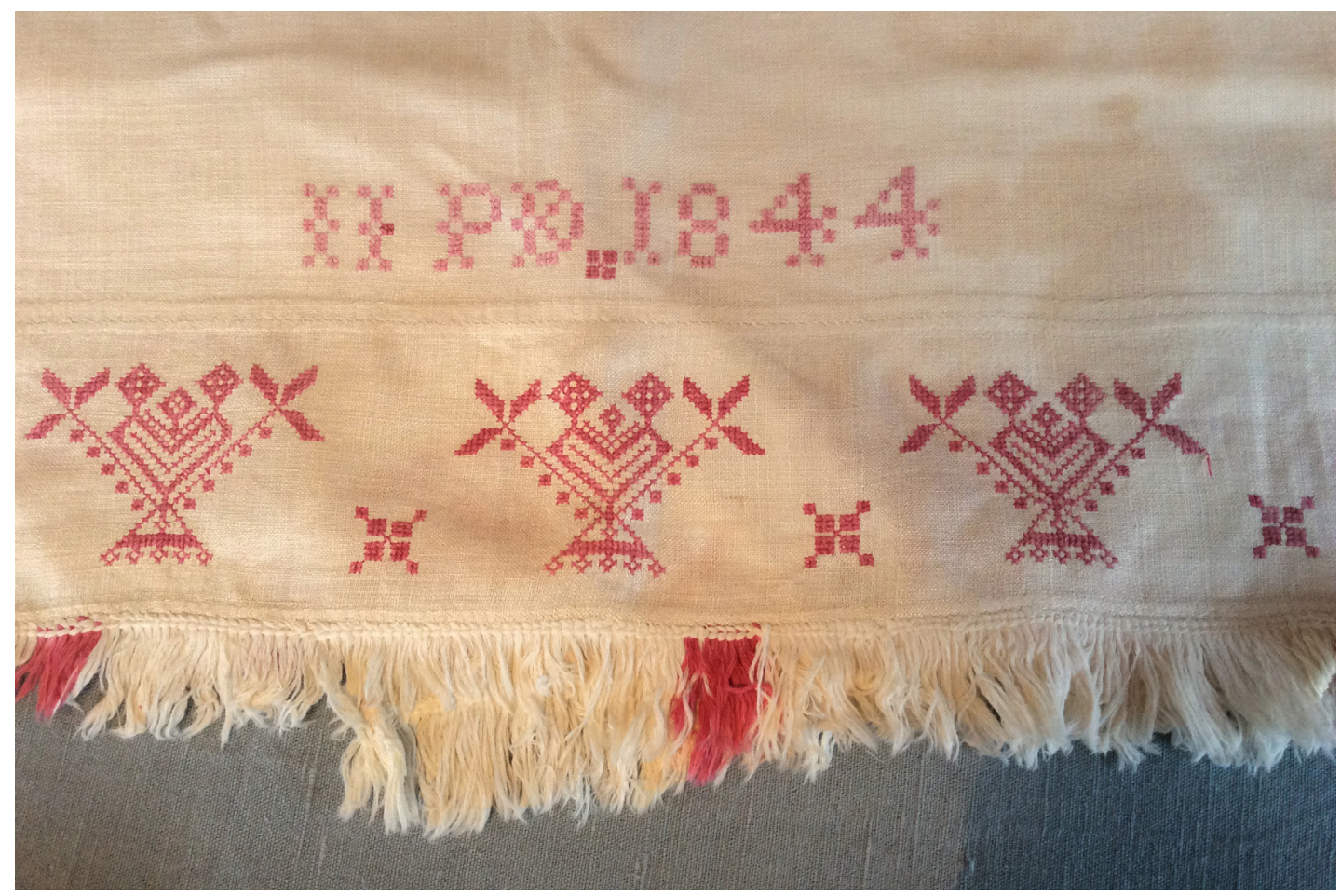


folkkonst, är att uppmärksamma de skilda teknikernas förutsättningar. Att väva innebär till exempel att skapa en yta linjärt, där varptrådarna bildar grunden för inslagen som adderas efter hand. Mönster och dekor byggs upp genom den vävteknik som används tillsammans med färgvariationer. Den vävda ytan kan jämföras med pixlar, där varje möte mellan varp och inslag bildar en punkt (Ekdahl 2017). Vävningen i sig skapar därför möjligheter för geometriska mönster. Fria broderier inbjuder å andra sidan till mer rundade former där nålen och tråden kan användas för att skapa andra typer av mönster och dekorer. Möjligheten att skapa mönster genom flätning styrs av antal knippen av trådar och att arbeta med fyra stycken, som i Hälsingland, ger förutsättningar för ett annat slags mönstring än med tre knippen som i södra Sverige (jfr Palmsköld 2007). Estetiska möjligheter och variationer, val av hantverksteknik och tillgång till färger hänger alltså samman. Ett sätt att se på betydelsen av mönster och dekorer är att betrakta dem som uttryck för skicklighet och med Lilli Zickermans ord för kvinnors skicklighet att skapa textilkonst. Ett annat sätt att uttrycka det är att tala om att tekniker, material och färger erbjuder och skapar möjligheter som hantverkaren kan använda sig av. Hantverksskicklighet handlar då om att på bästa sätt utnyttja dessa möjligheter och skapa variation. Med en sådan utgångspunkt är estetiska variationer genom mönster och dekorer uttryck för hantverkarens skicklighet.

\section{Referenser}

\section{Otryckta källor}

Delsbo hembygds- och fornminnesförening, textilsamlingen.

Hälsinglands museum, textilsamlingen.

Järvsö hembygdsförening, textilsamlingen. XJG T 1490, XJG 98, XJG 666.

Ljusdalsbygdens museum, textilsamlingen.

Loos kommunarkiv. Olof Perssons arkiv, Fågelsjö socken.

Nordiska museets samlingar och arkiv. EU 2214; NM 2995 Dyna; NM 122709 Rya; NM 125706 Kuddvar; NM 117314 a-p Spetsprover; NM 204685 Rya.

Lilli Zickermans manuskript till verket Sveriges folkliga textilkonst. Vol. 1: Sveriges folkliga textilkonst del I samt Krabbasnår, del II; Vol. 3: Rosengång, del VI; Vol. 6: Flossa, del XI, bd I; Vol. 7: Flossa, del XI, bd II; Vol. 8: Flossa, del XI, bd III; Vol. 9: Linnebottenstäcken, del XII, bd I; Vol. 10: Linnebottenstäcken, 
del XII, bd II; Vol. 12: Broderi på linne, del XVI, bd I; Vol. 13: Broderi på linne, del XVI, bd II och III; Vol. 17: Flätning, del XIII, bd II; Vol. 23: Knyppling, del XIX, bd II; Vol. 26: Knytning, del XX.

Privata samlingar, textilier.

Samtal med Anders Assis, 2015-02-17.

Lilli Zickermans studiesamling. HSZ.2-00109 Kuddhuva/örngott. www.digitaltmuseum.se [2018-08-03].

\section{Tryckta källor}

Bergström, Eva (2013). Den blå handen: om Stockholms färgare 1650-1900. Stockholm: Nordiska museets förlag.

Boëthius, Gerda (u.å). Hemslöjden. u.o.: s. 453-482.

Broderi. www.rikstermbanken.se [2019-08-26].

Danielson, Sofia (1986). Stina Rodenstam: ideolog och organisatör i 1900-talets hemslöjdsarbete. Stockholm: Nordiska museet.

Eldvik, Berit \& Brita Åsbrink (1979). Järvsösöm. Stockholm: LT.

Ekdahl, Annika (2017). Gobelängresan: boken om att följa hjortar. Göteborg: Göteborgs universitet, Institutionen för kulturvård.

Grenander Nyberg, Gertrud (1983). Lanthemmens prydnadssöm: studier av svenskt folkligt broderi på hemtextilier före 1900. Stockholm: Nordiska museet.

Hemslöjdens samlingar. www.digitaltmuseum.se [2019-08-26].

Karlin, Georg (1886). Skånsk textil konstslöjd. Lund: Kulturhistoriska föreningen.

Martinsen, Hanna E. H. (2001). Dyeing in the Eighteenth Century. Annals of Science, 58:4, s. 399-402.

Nylén, Anna-Maja (1995). Hemslöjd: den svenska hemslöjden fram till 1800-talets slut. Ny utg. Stockholm: Cordia.

Nyström Ingalill, Susanne Wilken \& Jacob Thomas (2016). FT-Raman Analyses of Blue Dyes Stuff Common in Swedish Folk Art from Hälsingland during 18th and 19th Century. The Journal of Chemical Sciences 7:123. doi:10.4172/21503494.1000123

Nyström, Ingalill \& Andreas Roxvall (2018). Färgväxten vejdes användning i Sverige under 1700 - och 1800-talen. En källöversikt. Rig: kulturhistorisk tidskrift 2018:2-3.

Olars, Katarina (2015). Hälsingegårdarnas textila färglandskap: tänkbara kulörer, färgämnen och färgningsmetoder i Hälsingland 1750-1870. Kandidatuppsats i kulturvård, Konservatorsprogrammet 2015:12. Göteborg: Göteborgs universitet, Institutionen för kulturvård.

Palmsköld, Anneli (2007). Textila tolkningar: om hängkläden, drättar, lister och takdukar. Diss. Lund: Lunds universitet.

Palmsköld, Anneli (2012a). Begreppet hemslöjd. Stockholm: Hemslöjdens förlag.

Palmsköld, Anneli (2012b). Begreppet hemslöjd idag. I: Meister, Anna (red.). Lilli \& Prinsen: 100 år av hemslöjd och textil konst. Stockholm: Carlsson Bokförlag.

Palmsköld, Anneli (2017). Den omoraliska virkningen. I: Jönsson, Lars-Eric (red.). Politiska projekt, osäkra kulturarv. Lund: Lunds universitet.

Palmsköld, Anneli (2018). Emma Carolina Helena (Lilli) Zickerman. Svenskt kvinno- 
biografiskt lexikon. https://skbl.se/sv/artikel/LilliZickerman (kontrollerad 202007-13)

Palmsköld, Anneli \& Anna Fabler (2018). Turkisk rödfärgning: tolkning av historiska färgrecept. Rig: kulturhistorisk tidskrift 2018:2-3.

Rodenstam, Greta (1969). Näversömmen i Hälsingland. Förord och historik. I: Fischer, Tyra (red.). Mönsterbok i näversöm från Hälsingland. Delsbo: Tyra Fischer.

Rodenstam, Stina (1986). Hälsinglands textila hemslöjd. Stockholm: Nordiska museet.

Runefelt, Leif (2015). Grå bonde, blå bonde. I: Wachenfeldt, Paula von \& Klas Nyberg (red.). Det svenska begäret: sekler av lyxkonsumtion. Stockholm: Carlsson Bokförlag.

SAOB (Svenska Akademiens Ordbok), rosengång. www.saob.se, [2018-08-03].

Thomasson, Elin (2015). Färgad av kulturarvet: Utövarperspektiv på växtfärgning som kulturarv. Kandidatuppsats i Kulturvård, Ledarskap i slöjd och kulturhantverk, 2015:29. Göteborg: Göteborgs universitet, Institutionen för kulturvård.

Zickerman, Lilli (1937). Sveriges folkliga textilkonst: utdrag ur Föreningens för svensk hemslöjds samlingsverk över svenska allmogetextilier, del 1, Rölakan. Stockholm: Svensk litteratur.

Zickerman, Lilli (1999). Lilli Zickermans bästa: hemslöjdstankar från källan. Umeå: Hemslöjden.

Åsbrink, Brita \& Gun Blomqvist (1970). Järvsösöm. Stockholm: LT. 